\title{
The promising potential of piperlongumine as an emerging therapeutics for cancer
}

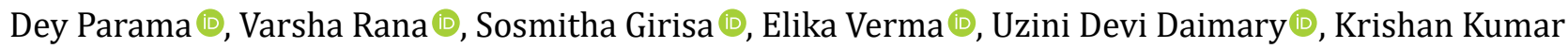 \\ Thakur ${ }^{\circledR}$, Aviral Kumar ${ }^{\circledR}$, Ajaikumar B. Kunnumakkara* ${ }^{*}$
}

Cancer Biology Laboratory and DBT-AIST International Center for Translational and Environmental Research (DAICENTER), Department of Biosciences and Bioengineering, Indian Institute of Technology Guwahati, Assam 781039, India

*Correspondence: Ajaikumar B. Kunnumakkara, Cancer Biology Laboratory, Department of Biosciences and Bioengineering,
Indian Institute of Technology Guwahati, Guwahati, Assam 781039, India. kunnumakkara@iitg.ac.in; ajai78@gmail.com
Academic Editor: Jianxun Ding, Changchun Institute of Applied Chemistry, Chinese Academy of Sciences, China
Received: March 22, 2021 Accepted: July 4, 2021 Published: August 30, 2021

Cite this article: Parama D, Rana V, Girisa S, Verma E, Daimary UD, Thakur KK, et al. The promising potential of piperlongumine as an emerging therapeutics for cancer. Explor Target Antitumor Ther. 2021;2:323-54. https://doi. org/10.37349/etat.2021.00049

\begin{abstract}
In spite of the immense advancement in the diagnostic and treatment modalities, cancer continues to be one of the leading causes of mortality across the globe, responsible for the death of around 10 million patients every year. The foremost challenges faced in the treatment of this disease are chemoresistance, adverse effects of the drugs, and the high cost of treatment. Though scientific studies over the past few decades have foreseen and are focusing on the cancer-preventive and therapeutic potential of natural products and their underlying mechanism of action, many more of these agents are not still explored. Piperlongumine (PL), or piplartine, is one such alkaloid isolated from Piper longum Linn., which is shown to be safe and has significant potential in the prevention and therapy of cancer. Numerous shreds of evidence have established the ability of this alkaloid and its analogs and nanoformulations in modulating various complex molecular pathways such as phosphatidylinositol-3-kinase/protein kinase B/mammalian target of rapamycin, nuclear factorkappa B, Janus kinases/signal transducer and activator of transcription 3, etc. and inhibit different hallmarks of cancer such as cell survival, proliferation, invasion, angiogenesis, epithelial-mesenchymal-transition, metastases, etc. In addition, PL was also shown to inhibit radioresistance and chemoresistance and sensitize the cancer cells to the standard chemotherapeutic agents. Therefore, this compound has high potential as a drug candidate for the prevention and treatment of different cancers. The current review briefly reiterates the anti-cancer properties of PL against different types of cancer, which permits further investigation by conducting clinical studies.
\end{abstract}

\section{Keywords}

Piperlongumine, piplartine, Piper longum Linn., cancer, signaling pathways, chemotherapy, radiotherapy, toxicity 


\section{Introduction}

Regardless of the notable progress achieved in cancer diagnosis and treatment, it is still considered as one of the most dreadful and prevalent diseases having very high morbidity and mortality rate [1-10]. There are diverse types of cancer, all of which are associated with atypical growth and proliferation of cells leading to approximately 10 million deaths per year [11-16]. The majority of cancers occur due to genetic mutations associated with lifestyle and environmental-related factors, although some of the cancer types are caused because of inherited genetic makeup [10,17]. A considerable proportion of the global cancer burden can be relieved by evading the risk factors, such as consumption of carcinogenic products, poor diet, and absence of physical activity leading to obesity, sexually transmitted diseases, and pollution, to name a few [17]. A diverse range of drugs have been discovered and screened with the aim to cure this disease in the last few decades. However, most of the standard chemotherapeutics fail to provide complete relief to the patients and are further known for imparting innumerable side effects and secondary diseases like myelosuppression, nausea, vomiting, heart diseases, hepatic dysfunction, hypertension, malaise, etc. In addition, extensive use of those drugs also results in the development of chemoresistance in cancer cells [18-22]. Therefore, advances in the development of novel, non-toxic, effectual, and cost-effective therapeutic modalities are an urgent requirement for the management of this life-threatening disease.

Since ancient times, plant-derived phytochemicals and herbal medicines are being explored as a treatment modality against different chronic diseases, including cancer, and thus have gained extensive popularity for possessing beneficial healing properties [23-35]. The healing properties of the plant-derived products are due to the presence of a wide range of biologically active alkaloids, flavonoids, tannins, diterpenoids, carotenoids, and phenolic compounds present in various parts [36-42]. Therefore, these compounds play a vital role in preventing cancer initiation and suppressing the process of cell proliferation, invasion, metastasis, and chemoresistance [43-52]. Interestingly, it was reported that, almost one-third of all the emerging drugs approved by the United States Food and Drug Administration (US FDA) consist of natural products either in their native form or their analogs [19, 53, 54]. Even though experts across the globe pay more attention to exploring the anti-inflammatory, anti-oxidant, anti-cancer, chemosensitizing, and radiosensitizing potential of the active compounds extracted from natural sources, several other phytochemicals are still left to be recognized [41, 53, 55-59].

Piperlongumine (5,6-dihydro-1-[(2E)-1-oxo-3-(3,4,5-trimethoxyphenyl)-2-propenyl]-2(1H)-pyridinone, PL; Figure 1), also known as piplartine, is the major active alkaloid present in the fruits and roots of Piper longum Linn., commonly known as long pepper or "Pippali" belonging to the Piperaceae family [60-63]. Accumulating lines of evidence have documented its role in cancer prevention, and it is reported to be effective against many human cancer cell lines of breast, colon, liver, lung, prostate, skin, and thyroid. As PL is a naturally occurring alkaloid, it is comparatively less toxic, and it can also concomitantly modulate the expression of various target genes, thereby imparting potential anti-cancer effects [62].

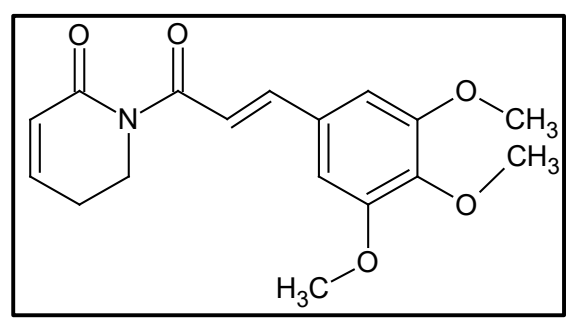

Figure 1. Chemical structure of PL

\section{Sources of PL}

PL is extracted from the fruits and roots of P. longum L. (Figure 2), and was first isolated and characterized in 1963 [60,64]. The plant grows in the wild tropical rain forests of India, Indonesia, Malaysia, Rhio, Timor, Nepal, Philippines, and Sri Lanka [65]. It has also been grown indigenously in India, along with cultivation in tropical and subtropical areas of Asian and Pacific islands [66]. 


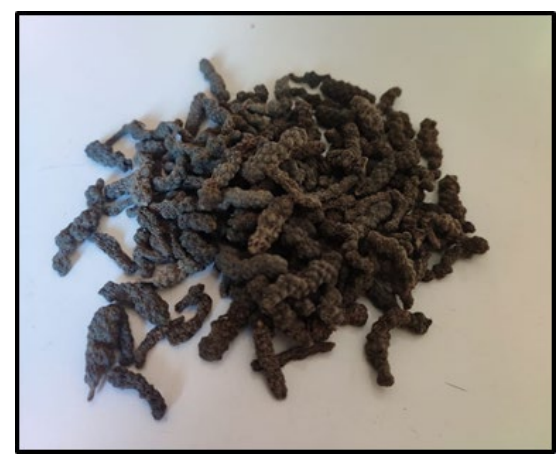

Figure 2. Source of PL

\section{Biosynthesis and chemistry of PL}

The chemical structure of PL is composed of two $\alpha, \beta$-unsaturated imide functionalities [67]. The structure of PL was first determined in 1968, and generally, the linkage of 5,6-dihydropyridin-2(1H)-one to a 3,4,5-trimethoxyphenyl group via an E-acryloyl group form a molecule of PL [68]. Using the same components, He et al. [69] synthesize PL. The 5,6-dihydropyridin-2(1H)-one synthesized from commercially available 2-piperidone acted as one of the precursors. Another precursor, 3,4,5-trimethoxycinnamic acid, was converted to acyl chloride 3,4,5-trimethoxycinnamic acid using an oxalyl chloride. Then the sodium hydride deprotected 5,6-dihydropyridin-2(1H)-one was allowed to react with (E)-3-(3,4,5-trimethoxyphenyl) acryloyl chloride that gave rise to the resultant compound PL [69].

Similarly, Sun et al. [70] has synthesized PL by adding acyl chloride (or acid anhydride) to a 5,6-dihydropyridin-2(1H)-one and incubating the solution at $0^{\circ} \mathrm{C}$ followed by the addition of sodium hydride, and the solution was kept at $0^{\circ} \mathrm{C}$ for a couple of hours and then stirred for the next $18 \mathrm{~h}$ at room temperature in dry air. The solution was then transferred into ice water, and subsequent extraction was done with ethyl acetate. The organic phases were dried, concentrated, and purified to get the final product PL and its analogs through the flash column chromatographic method [70].

Another group has reported that the synthesis of PL involves the fusion of $\alpha, \beta$-unsaturated $\delta$-lactam with the cinnamates [71]. The $N$-Boc protection of the commercial compound, $\delta$-valerolactam, using the di-tert-butyl dicarbonate leads to the synthesis of $\alpha, \beta$-unsaturated $\delta$-lactam with $98 \%$ yield. The $N$-Boc protected lactam compound derived from $\delta$-valerolactam is converted to 3-(phenylthio) piperidin-2-one with the complementary treatment of freshly prepared lithium diisopropylamide and diphenyl disulfide [71]. The sulfide is then allowed to oxidize. The resultant sulfoxide is thermally eliminated, which gives rise to $\alpha, \beta$-unsaturated $\delta$-lactam, and it's the $N$-Boc deprotection in an acidic environment that produced the desired lactam molecule. The phosphonoacetamide is then synthesized from lactam through the Arbuzov reaction. It is then allowed to mediate sodium hydride deprotonation and react with 3,4,5-trimethoxybenzaldehyde, giving rise to PL with 51\% yield [71]. The 3,4,5-trimethoxybenzyl in PL is an anti-cancer exhibiting moiety that is employed in synthesizing the PL derivatives such as L50377 to improve anti-cancer efficacy [72].

PL is also combined with metal complexes such as ruthenium and platinum to increase its anti-cancer efficiency [73, 74]. In line with this, a novel PL and ruthenium complex was synthesized from two precursor complexes, such as $\left[\mathrm{RuCl}_{2}(\mathrm{~N}-\mathrm{N})(\mathrm{P}-\mathrm{P})\right]$ and 1,4-bis(diphenylphosphino)butane $[73,75]$. Further, platinumbased PL derivatives were also synthesized using the demethylated PL, PIP-OH ligand that was allowed to react with the platinum precursor $\mathrm{PtCl}_{2}\left(\mathrm{PPh}_{3}\right)_{2}$, and through the exchange of one chloride molecule, it resulted in a novel platinum-based PL complex, i.e., cis-[PtCl(PIP-OH) $\left.\left(\mathrm{PPh}_{3}\right)_{2}\right] \mathrm{PF}_{6}[74]$.

\section{Biological activities of PL}

A plethora of studies have reported multiple biological properties of $P$. longum L., including anti-arthritic, anti-asthmatic, anti-diabetic, anti-epileptic, anti-inflammatory, anti-microbial, anti-oxidant, anti-stress, anti-tumor, anti-ulcer, as well as immunomodulatory properties [61, 66]. A study demonstrated the hepatoprotective effects of $P$. longum via decreasing the rate of lipid peroxidation and increasing glutathione (GSH) levels [76]. Furthermore, administration of the roots of $P$. longum displayed 
high antifertility effects [65]. Another study conducted by Khushbu et al. [77] has demonstrated the cardioprotective effect of $P$. longum against biochemical and histopathological damages in rat models suffering from acute myocardial infarction. Furthermore, the anti-thrombogenic properties of PL ( $50 \mathrm{mg} / \mathrm{kg}$ ) were also observed in the pulmonary thrombosis mice model [78]. PL was also found to inhibit an essential rate-limiting enzyme, human aldose reductase, involved in the conversion of glucose to sorbitol. Diabetic complications are generally associated with sorbitol accumulation. Therefore, these insights point towards the anti-diabetic effects of PL [79].

Furthermore, a novel PL-mediated therapeutic strategy for atherosclerosis plaque revealed that PL acted via the suppression of platelet-derived growth factor (PDGF) receptor signaling [80]. An in vivo study demonstrated the anti-depressant and anxiolytic effects of PL through experimental analyses including open field, forced swimming tests, and elevated plus maze [81]. Interestingly, the synergistic effects of PL have also been observed with existing anti-bacterial drugs, including tetracycline and rifampicin, thereby improving their effectiveness [82]. Thus, the above reported biological properties reflect the vast therapeutic potential of PL in the treatment of various anomalies.

\section{Molecular targets of PL}

A plentiful of studies have evidenced the multi-targeted nature of PL, which contributes to its diverse pharmacological activities. It was found to modulate the important cell signaling pathways such as phosphatidylinositol-3-kinase (PI3K)/protein kinase B (Akt)/mammalian target of rapamycin (mTOR), nuclear factor-kappa B (NF- $\kappa$ B), Janus kinases (JAK)/signal transducer and activator of transcription 3 (STAT3), and extracellular signal-regulated kinase (ERK) which play a critical role in regulating the processes involved in the initiation, development, and progression of cancer. PL significantly downregulated the mRNA expression of the cell cycle regulatory genes such as cyclin B1, cyclin D1, cyclin-dependent kinases $(C D K)-1$, $C D K 4, C D K 6$, and proliferating cell nuclear antigen (PCNA) [83]. This compound also modulated the expression of cell survival and invasion associated genes such as heme oxygenase 1 (HMOX1), heat shock protein family A member 1A (HSPA1A), caspase-3 (CASP3), cyclin dependent kinase inhibitor 1A (CDKN1A), MYC, phosphatidylinositol-4,5-bisphosphate 3-kinase catalytic subunitgamma (PIK3CG), B-cell lymphoma 2(Bcl-2),

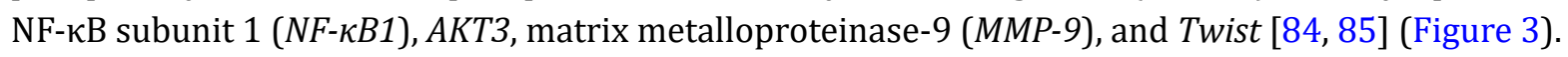

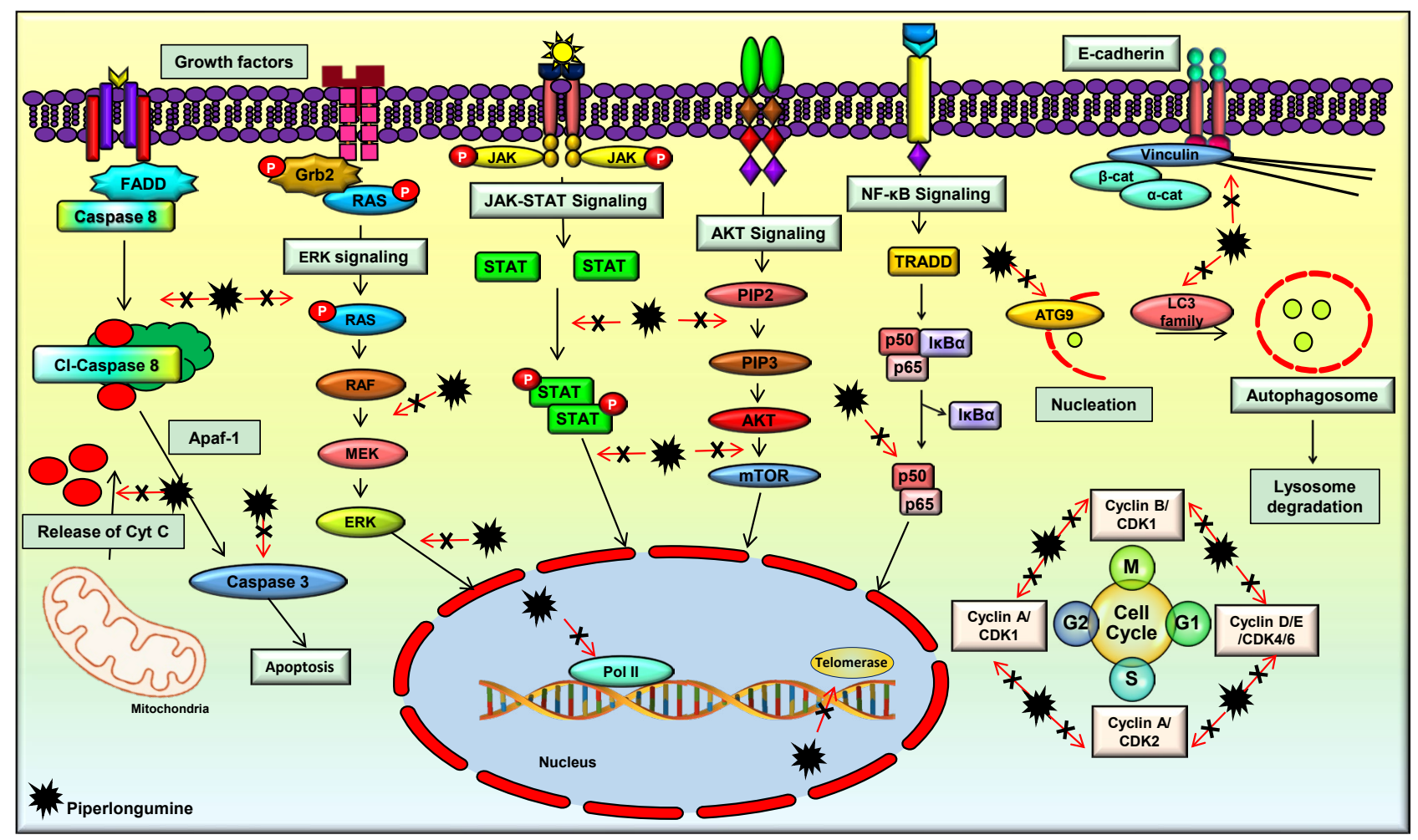

Figure 3. PL regulates the molecular targets and various signaling pathways involved in cancer progression 


\section{PL and PI3K/Akt/mTOR signaling}

The PI3K/Akt/mTOR pathway is an important cell signaling pathway that has a critical role in several cellular processes such as proliferation, growth, and cellular metabolism. The abnormality of this signaling pathway is a common cause of cancer, and many studies reported the downregulation of this pathway by PL [86-89]. For instance, PL was found to suppress this pathway in breast cancer cells, which led to cell apoptosis and autophagy [90]. In addition, inhibition of this pathway following PL treatment was observed in cervical cancer, colorectal cancer (CRC), and lung cancer cells as well, which resulted in the prevention of tumor growth [90-93]. Further, suppression of the Akt/mTOR pathway by PL was also associated with the partial inhibition of glycolysis, as suggested by a study on lung cancer cells [94]. Additionally, suppression of the Akt/mTOR signaling pathway by PL in renal cell carcinoma cells was demonstrated to be reactive oxygen species (ROS) dependent, which led to cell death and inhibition of tumor initiation and progression [90]. Furthermore, PL treatment suppressed lung tumor growth in an in vivo model by inhibiting the PI3K/Akt/ mTOR pathway [95]. As this pathway regulates many other processes involved in cancer development and progression, further studies are warranted to delineate the effect of PL on these processes, which would pave the way in the management of different malignancies. In addition, novel analogs of PL and their interaction with this pathway can be explored, which would help to develop novel Akt/mTOR inhibitors for the treatment of different cancers.

\section{PL and NF- $\mathrm{\kappa B}$ signaling}

The NF- $\mathrm{B}$ signaling pathway is known to play an active role in cell survival and proliferation. It regulates numerous physiological processes such as development, differentiation, inflammation, immunity, and metabolism in the initial and later stages of cancer [96-99]. Therefore, the agents that suppress the activation of this pathway have high potential in the prevention and treatment of cancer [98]. Suppression of the NF- $\kappa B$ signaling pathway and its related genes by PL was reported in different cancers [83]. Further, an in vitro study demonstrated that PL treatment caused ROS-dependent inactivation of the inhibitor of NF- $\mathrm{BB}$ kinase subunit beta (IKK $\beta$ ), which ultimately caused inhibition of the NF- $\kappa B$ signaling pathway in breast cancer

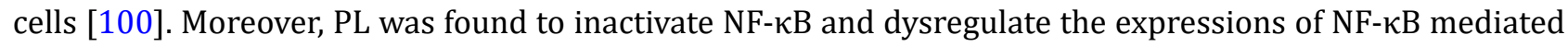
proteins, thereby inhibiting metastasis in prostate cancer cells [101]. Furthermore, an in vivo study of lung cancer showed that PL modulated the components of the NF- $\kappa B$ signaling pathway, and inhibited tumor growth [102]. These studies suggest that PL and its analogs may have high potential in deactivating the NF- $\mathrm{B}$ pathway, which is constitutively expressed in different cancers.

\section{PL and JAK/STAT3 signaling}

JAK/STAT3 signaling pathway is known to regulate the cellular processes involved in cell survival, cell division, invasion, angiogenesis, migration, metastases, chemoresistance, and radioresistance. JAK/STAT signaling is found to be active in different types of human malignancies and promotes tumorigenesis [18, 84, 103-108]. An in vitro study on gastric cancer cells has demonstrated that PL efficiently inhibited cell proliferation, invasion, and migration by blocking the JAK1,2/STAT3 signaling pathway [109]. Furthermore, PL was found to distinctly repress STAT3 activity independent of the phosphorylation of JAK2, which is an upstream regulator of STAT3. Further, the downstream regulators of STAT3, such as c-myc, p21, p27, and survivin, were modulated by PL [110]. Another group synthesized a series of PL derivatives and demonstrated that one of the derivatives, namely CG-06, could suppress the activation of STAT3 by directly binding to it and partly through ROS generation. The derivative was found to be more effective than PL [111]. However, further studies are required to decipher the exact mechanism of STAT3 suppression by PL and its analogs which pave the way in developing therapies against different cancers.

\section{PL and ERK signaling}

ERK is an important cell signaling pathway that is mainly associated with the induction of autophagy [112]. The effect of PL on the ERK pathway was studied on biliary cancer cell lines, which revealed that PL treatment resulted in ROS mediated activation of the ERK pathway, which ultimately induced autophagy in these 
cells [112]. In addition, this compound increased the levels of intracellular ROS and imparted ROS-dependent cell death via stimulation in c-Jun N-terminal kinase (JNK) and ERK levels. Further, suppression of proteasome activity by PL also imparts to cancer cell death [113]. PL also negatively regulates ERK1/2 signaling pathways, thereby suppressing the level of c-Fos in CRC cells [93]. Additionally, PL was shown to inhibit MEK/ERK signaling in a dose and time-dependent manner, leading to CRC cell death [114]. Moreover, PL was shown to modulate the expression of ERK1/2 and induce cytotoxicity in lung cancer cells [91]. As this pathway is expressed in many other cancers, further investigation on the effect of PL on the proteins involved in this pathway is warranted.

\section{Other targets}

Apart from the aforementioned signaling pathways, PL was found to target a wide range of proteins that play a key role in cancer development. For instance, PL regulated the expressions of critical proteins involved in apoptosis such as Bcl-2, Bcl-2 associated $\mathrm{X}$ apoptosis regulator (Bax), Bcl-2 associated agonist of cell death (Bad), B-cell lymphoma-extra-large (Bcl-xL), X-linked inhibitor of apoptosis protein (XIAP), poly (ADP-ribose) polymerase (PARP), and caspases [113, 115-117]. PL was also shown to modulate microtubule-associated protein 1 light chain 3 (LC3), which is considered as one of the important markers of autophagy $[90,118]$. A handful of studies also suggested that PL-induced G2/M phase cell cycle arrest by acting on the cell cycle regulatory proteins such as cyclin B1, cyclin D1, CDK1, CDK4, CDK6, and PCNA [100]. PL also increased the expression of growth arrest and DNA-damage-inducible alpha (GADD45 $\alpha$ ) in gastric cancer cells and downregulated the levels of cdc2 to induce cell cycle arrest [119]. Additionally, PL inhibited the invasiveness and metastatic potential of prostate cancer cells by modulating the expressions of interleukin (IL)-6, IL-8, and MMP-9 [101]. In addition, PL was found to downregulate slug and upregulate E-cadherin and inhibited epithelial-mesenchymal transition (EMT) in breast cancer cells [120]. PL was also found to inhibit transforming growth factor-beta (TGF- $\beta$ )-induced EMT in breast and lung cancer cells by modulating the expressions of E-cadherin, Snail1, and Twist1 [121]. These studies clearly indicate that PL is a multi-targeted agent and can be used to target multiple deregulations in different cancers.

\section{Anti-cancer activities of PL}

Increasing lines of evidence suggest that PL has been found to impart potential anti-cancer activities both in vitro and in vivo. Studies over the years [64, 85, 90-95, 100-102, 109-117, 119-149], have reported the potential of this alkaloid to be used both directly as an anti-cancer drug (Figure 4, Table 1) and in combination with the standard chemotherapeutic drugs (Table 2) to enhance their efficacy. The following section describes the anti-cancer properties of PL in different cancers and its mechanism of action.

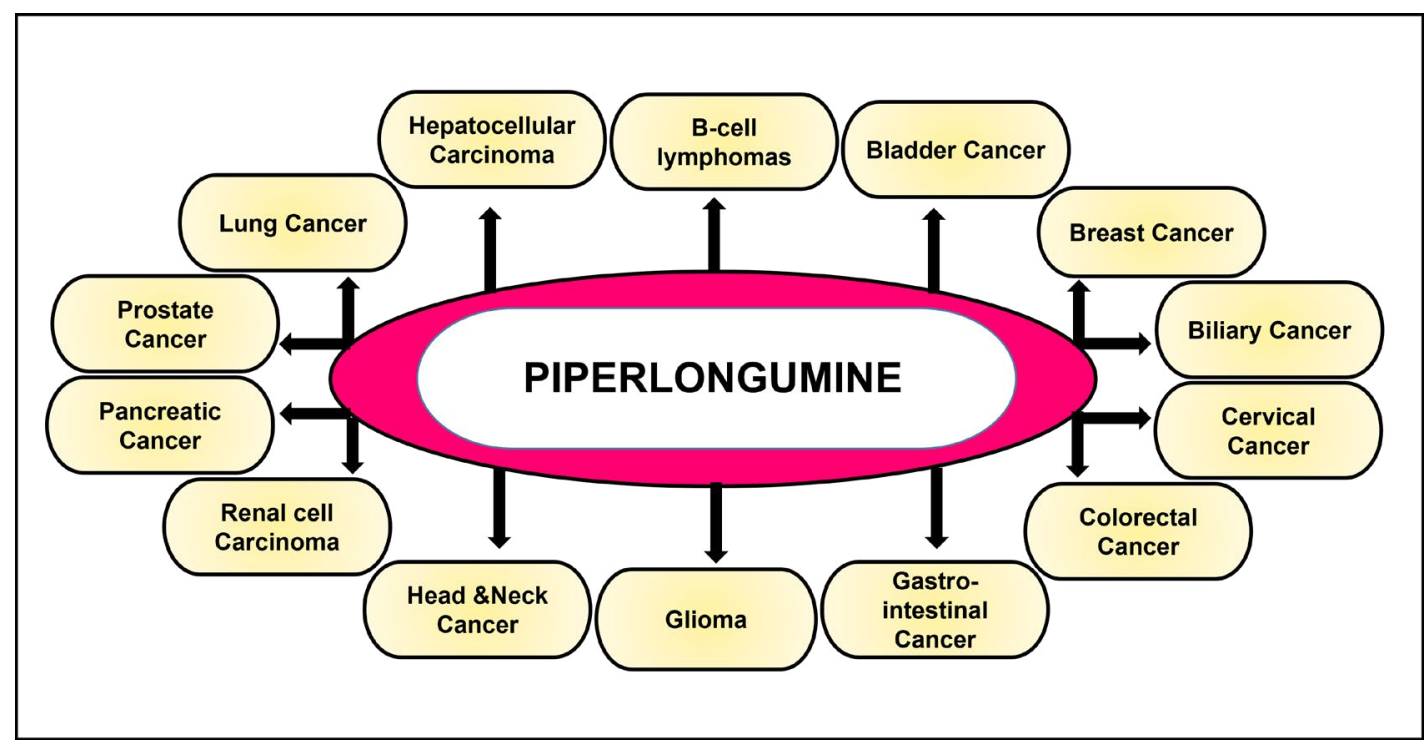

Figure 4. Anti-cancer activity of PL 
Table 1. Mechanism of action of PL against different cancers

\begin{tabular}{|c|c|c|c|c|}
\hline Cancer & In vitro/In vivo & Model & Outcome/Mechanism & References \\
\hline \multirow[t]{2}{*}{ ABC-DLBCL } & In vitro & OCI-Ly10, U2932, DB & $\uparrow$ Apoptosis, $\downarrow$ Bcl-2, $\downarrow$ survivin, $\uparrow$ Bax & [122] \\
\hline & & $\uparrow p 21, \downarrow N F-k B$ & & \\
\hline \multirow[t]{2}{*}{ Bladder cancer } & In vitro & T24, BIU-87, EJ & G2/M phase arrest, $\downarrow$ GSH & [123] \\
\hline & In vivo & T24 xenograft & $\begin{array}{l}\text { G2/M phase arrest, } \downarrow \beta \text {-catenin, } \downarrow \text { ZEB1, } \\
\downarrow N \text {-cadherin, } \downarrow \text { claudin- } 1, \downarrow \text { ZO- } 1, \downarrow \text { Slug }\end{array}$ & \\
\hline Biliary cancer & In vitro & HuCCT-1, OCUG-1 & $\begin{array}{l}\text { G2/M phase arrest, } \uparrow \text { apoptosis, } \uparrow p-E R K \\
\uparrow L C 3-I I, \text { ROS }\end{array}$ & [112] \\
\hline \multirow[t]{12}{*}{ Breast cancer } & In vitro & MCF-7 & $\begin{array}{l}\downarrow \text { Akt/mTORC } 1, \downarrow \text { GSK-3 } \beta, \downarrow \text { TSC2, } \downarrow 4 \mathrm{E}- \\
\text { BP1, } \downarrow \text { p70S6K, } \uparrow \text { LC3-II, } \uparrow \text { autophagy }\end{array}$ & {$[90]$} \\
\hline & In vitro & MDA-MB-231, BT-549, Hs578T & $\begin{array}{l}\text { Growth, } \downarrow \text { metastasis, } \downarrow \text { EMT, } \downarrow \text { ZEB1, } \\
\downarrow \text { slug, } \uparrow \text { E-cadherin, } \downarrow \text { MMP2, } \downarrow \text { MMP9, } \\
\uparrow \text { miR-200c, } \downarrow \text { IL-6, } \uparrow \text { ROS, } \uparrow \text { autophagy }\end{array}$ & [120] \\
\hline & In vitro & MDA-MB-468, MCF-7 & $\begin{array}{l}\downarrow \text { Proliferation, } \uparrow \mathrm{G} 2 / \mathrm{M} \text { arrest, } \uparrow \text { apoptosis, } \\
\downarrow \text { topoisomerase II, } \uparrow \mathrm{p} 53, \uparrow \mathrm{p} 21, \downarrow \mathrm{Bcl}-2, \\
\uparrow \text { Bax, } \uparrow \text { Cyt C, } \uparrow \text { caspase- } 3, \uparrow \text { caspase-7, } \\
\uparrow \text { caspase-8 }\end{array}$ & [116] \\
\hline & In vitro & BT474, MCF7, SkBr3 & $\downarrow p$-HER1, $\downarrow p$-HER2, $\downarrow$-HER3, $\uparrow$ ROS & [126] \\
\hline & In vitro & MCF-7, MCF-10A & $\uparrow$ Apoptosis, $\uparrow \mathrm{HO}-1, \uparrow \mathrm{Nrf2}$ & [213] \\
\hline & In vitro & MCF-7 & $\begin{array}{l}\uparrow B I M, \uparrow c l e a v e d \text { caspase- } 9 \text { and } \\
\text { caspase- } 3, \downarrow p \text {-FOXO3A, } \downarrow \text { p-Akt }\end{array}$ & [92] \\
\hline & In vivo & MCF-7 xenograft & $\downarrow$ tumor growth, $\downarrow p-F O X O 3 A, \uparrow B I M$ & [92] \\
\hline & In vitro & SKBR3 & $\begin{array}{l}\uparrow \text { apoptosis, } \uparrow \text { ROS, } \downarrow \text { Sp } 1, \downarrow \text { Sp3, } \downarrow \text { Sp4, } \\
\downarrow \text { cMyc, } \downarrow \text { EGFR, } \downarrow \text { survivin, } \downarrow \text { cMET }\end{array}$ & [125] \\
\hline & In vitro & MCF-7 & $\begin{array}{l}\downarrow \text { SETDB } 1, \uparrow F o s B, \uparrow \text { cleaved PARP, } \\
\uparrow \text { caspase- } 9\end{array}$ & [117] \\
\hline & In vitro & MCF-7 & $\uparrow E$-cadherin, $\downarrow$ snail1, $\downarrow$ Twist1, $\downarrow$ cyclin D1 & [121] \\
\hline & In vitro & MCF-7 & $\downarrow \mathrm{CDK} 1, \mathrm{G} 2 / \mathrm{M}$ phase arrest & {$[100]$} \\
\hline & & & $\begin{array}{l}\downarrow \mathrm{CDK} 4, \downarrow \mathrm{CDK} 6, \downarrow \text { PCNA, } \downarrow \text {-CDK1, } \\
\uparrow \text { cyclin B1, } \uparrow \mathrm{ROS}, \downarrow \mathrm{GSH}, \downarrow \mathrm{p}-\mathrm{K} \mathrm{Ka}, \\
\downarrow \text { mRNA expression of cyclin B1, } \uparrow \mathrm{mRNA} \\
\text { p21 expression, } \downarrow \text { NF-kB activation }\end{array}$ & \\
\hline Cervical cancer & In vitro & HeLa & $\begin{array}{l}\uparrow B I M, \uparrow c l e a v e d \text { caspase- } 9 \text { and } \\
\text { caspase- } 3, \downarrow p-F O X O 3 A, \downarrow p-A k t\end{array}$ & [92] \\
\hline CCA & In vitro & $\begin{array}{l}\text { KKU-055, KKU-100, KKU-139, } \\
\text { KKU-213, KKU-214 }\end{array}$ & $\begin{array}{l}\text { G2/M phase arrest, } \uparrow \text { apoptosis, } \uparrow \text { ROS, } \\
\downarrow p-A k t, \uparrow B \text { Bd, } \downarrow \text { Bcl-2, } \uparrow \text { NQO1, } \uparrow \text { HO-1, } \\
\uparrow S O D 2, \uparrow p 21, \uparrow p \text {-ERK, } \uparrow p-J N K,\end{array}$ & [113] \\
\hline \multirow[t]{12}{*}{ CRC } & In vitro & $\begin{array}{l}\text { LOVO, SW480, HCT116, } \\
\text { HT29, HCT8, SW620 }\end{array}$ & $\begin{array}{l}\downarrow \text { Cell viability, } \downarrow \text { clonogenic potential, } \\
\downarrow \text { cyclin D1, } \downarrow \text { c-Fos, } \downarrow \text { p-EGFR } \\
\downarrow \text { ERK } 1 / 2\end{array}$ & [93] \\
\hline & In vivo & HT-29-xenograft & $\begin{array}{l}\downarrow \text { Tumor growth, } \downarrow \text { C-Fos and cyclin D1 } \\
\text { positive cells }\end{array}$ & [93] \\
\hline & In vitro & SW-620 & $\downarrow$ Proliferation & [116] \\
\hline & In vitro & 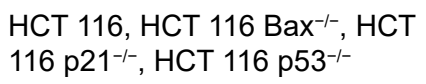 & G2/M phase arrest, $\uparrow$ apoptosis & [131] \\
\hline & In vivo & $\mathrm{DMH} \& \mathrm{DSS}$ induced & $\begin{array}{l}\downarrow \text { Tumor growth, G2/M phase arrest, } \\
\uparrow \text { apoptosis, } \downarrow \text { Bcl-2, } \uparrow \text { cleaved caspase-3, } \\
\downarrow \text { Ras, } \downarrow \text { cyclin D1, } \downarrow \text { NF-kB }\end{array}$ & [130] \\
\hline & In vitro & DLD-1 & $\begin{array}{l}\text { G2/M cell cycle arrest, } \uparrow \text { apoptosis, } \\
\uparrow R O S, \downarrow \text { GSH, } \downarrow \text { TrxR }\end{array}$ & [129] \\
\hline & In vitro & HT29, SW620, HCT116 & $\begin{array}{l}\uparrow N r f 2, \uparrow R O S, \uparrow B a x, \uparrow \text { cleaved caspase- } 3 \text {, } \\
\uparrow \text { cleaved PARP, } \uparrow M D M 2\end{array}$ & [132] \\
\hline & In vivo & HT-29-xenograft & $\begin{array}{l}\downarrow \text { Tumor growth, } \downarrow \text { tumor volume, } \downarrow \text { mutant } \\
\text { p53, } \uparrow \text { Bax, } \uparrow \text { cleaved PARP }\end{array}$ & [132] \\
\hline & In vitro & НТ-29, НCT 116 & $\uparrow$ Apoptosis, $\uparrow p$-ERK & [114] \\
\hline & In vivo & AOM/DSS induced & $\downarrow$ COX-2, $\downarrow$ IL-6, $\downarrow \beta$-catenin, $\downarrow$ snail & [128] \\
\hline & In vitro & HCT116 & $\uparrow a p o p t o s i s, \uparrow p-c-J u n$, JNK activation & [133] \\
\hline & In vitro & INT-407, HCT-116 & $\begin{array}{l}\uparrow \mathrm{ROS}, \downarrow \mathrm{FN} 1, \downarrow \mathrm{CDH} 2, \downarrow \mathrm{CTNNB} 1, \downarrow \mathrm{Bcl} 2, \\
\downarrow \text { survivin, } \uparrow \mathrm{p} 53, \uparrow \mathrm{Bax}, \uparrow \mathrm{SMAD} 4, \uparrow \mathrm{p} 21, \\
\downarrow \text { Twist }\end{array}$ & [127] \\
\hline
\end{tabular}


Table 1. Mechanism of action of PL against different cancers (continued)

\begin{tabular}{|c|c|c|c|c|}
\hline Cancer & In vitro/In vivo & Model & Outcome/Mechanism & References \\
\hline \multirow[t]{5}{*}{ Gastric cancer } & In vitro & AGS, HGC-27 & G2/M phase arrest, $\uparrow$ GADD45a, $\uparrow$ ROS & [119] \\
\hline & In vitro & SGC-7901, BGC-823 & $\begin{array}{l}\uparrow R O S, \downarrow \text { MDM-2, } \downarrow \text { cyclin B } 1, \downarrow \text { Cdc2, } \\
\text { G2/M phase arrest, } \uparrow p \text {-elF2 } 2 \alpha, \uparrow A T F 4, \\
\text { KATO III } \uparrow C H O P, \uparrow \text { apoptosis }\end{array}$ & [135] \\
\hline & In vivo & SGC-7901 xenograft & $\begin{array}{l}\uparrow R O S, \downarrow \text { TrxR } 1, \uparrow \text { cleaved caspase- } 3, \\
\uparrow C H O P, \uparrow M D A\end{array}$ & [135] \\
\hline & In vitro & MKN45, AGS & $\begin{array}{l}\text { G2/M phase arrest, } \downarrow \text { p-JAK1, } \downarrow \text { p-JAK2, } \\
\downarrow \text { p-STAT3, } \downarrow \text { Ki-67, } \downarrow \text { MMP-9, } \downarrow \text { Twist, } \\
\downarrow \text { cyclin D1 }\end{array}$ & [109] \\
\hline & In vitro & MGC-803 & $\begin{array}{l}\uparrow B I M, \uparrow \text { cleaved caspase- } 9 \text { and } \\
\text { caspase-3, } \downarrow \text {-FOXO3A, } \downarrow \text {-Akt }\end{array}$ & [92] \\
\hline \multirow[t]{2}{*}{ Glioma } & In vitro & HGG & $\begin{array}{l}\uparrow R O S, \downarrow P R D X 4, \uparrow \text { cleaved caspase- } 3 \text {, } \\
\uparrow P-H 2 A X, \uparrow C H O P, \uparrow p \text {-elF } 2 \alpha, \uparrow \text { apoptosis }\end{array}$ & [136] \\
\hline & In vitro & U87MG & $\begin{array}{l}\downarrow \text { Proliferation, } \uparrow \text { apoptosis, } \uparrow F O S, \uparrow R A F 1, \\
\uparrow N F K B 1, \uparrow N F K B 1 A, \uparrow N F K B 2, \uparrow P I K 3 C A, \\
\uparrow T P 53, \downarrow A K T 1, \downarrow A K T 2, \downarrow D V L 1, \downarrow E G F R, \\
\downarrow P I K 3 R 1, \uparrow P T E N, \uparrow B R A F, \downarrow K R A S\end{array}$ & [134] \\
\hline \multirow[t]{6}{*}{$\mathrm{HNC}$} & In vitro & $\begin{array}{l}\text { UMSCC1, UMSCC10A, } \\
\text { UMSCC17A }\end{array}$ & $\begin{array}{l}\uparrow \text { Apoptosis, } \uparrow \text { LC3-II, } \uparrow \text { ROS, } \uparrow 8-o x o-d G, \\
\downarrow \text { GSTP1 activity }\end{array}$ & [142] \\
\hline & In vivo & UMSCC10A xenograft & $\downarrow$ Tumor volume & [142] \\
\hline & In vitro & SAS, CGHNC8 & $\begin{array}{l}\downarrow \text { SOX2, } \downarrow \text { NANOG, } \downarrow \text { Oct- } 4, \uparrow E-c a d h e r i n, \\
\uparrow C K 18, \downarrow N \text {-cadherin, } \downarrow \text { vimentin, } \downarrow \text { snail, } \\
\downarrow \text { slug }\end{array}$ & [144] \\
\hline & In vivo & SAS \& CGHNC8 & $\downarrow$ Tumor weight, $\downarrow$ tumor growth & [144] \\
\hline & & xenograft & & \\
\hline & In vitro & OC2, OCSL & $\begin{array}{l}\downarrow \text { Proliferation, } \uparrow \mathrm{G} 0 / \mathrm{G} 1 \text { arrest, } \uparrow \mathrm{p} 21, \\
\uparrow \text { apoptosis, } \uparrow \mathrm{PARP}-1, \uparrow \text { caspase- } 3 \text {, } \\
\uparrow \text { senescence }\end{array}$ & [145] \\
\hline \multirow[t]{2}{*}{$\mathrm{HCC}$} & In vitro & HUH-7, HepG2 & $\begin{array}{l}\uparrow R O S, \downarrow \text { proliferation, } \uparrow \text { apoptosis, } \\
\downarrow \text { procaspase- } 3, \uparrow \text { Bax, } \uparrow \text { cleaved } \\
\text { caspase- } 3, \uparrow G 2 / M \text { arrest, } \uparrow A T F 4, \\
\uparrow p-e I F 2 \alpha, \uparrow p-P E R K, \downarrow \text { TrxR } 1, \downarrow \text { Bcl-2 }\end{array}$ & {$[64]$} \\
\hline & In vivo & HUH-7 xenograft & $\begin{array}{l}\downarrow \text { Tumor volume and weight, } \uparrow \text { ROS, } \\
\downarrow \text { TrxR1 }\end{array}$ & {$[64]$} \\
\hline \multirow[t]{12}{*}{ Lung cancer } & In vitro & A549 & $\downarrow$ Proliferation, $\uparrow$ cell death, $\downarrow$ migration & [143] \\
\hline & In vitro & A549, H1299 & $\uparrow A p o p t o s i s, ~ \uparrow R O S$ & [138] \\
\hline & In vitro & H1975, H23, HCC827 & $\downarrow \mathrm{HK} 2, \uparrow$ cleaved-PARP, $\uparrow$ caspase-3 & [94] \\
\hline & In vivo & $\begin{array}{l}\text { H1975 \& HCC827 } \\
\text { xenograft }\end{array}$ & $\begin{array}{l}\downarrow p \text {-Akt, } \downarrow \text { p-S6, HK2, } \downarrow \text { Ki- } 67, \downarrow \text { tumor } \\
\text { weight, } \downarrow \text { tumor growth }\end{array}$ & [94] \\
\hline & In vitro & A549, A549/DTX & $\begin{array}{l}\uparrow \text { Cleaved PARP, } \downarrow \text { Bcl-2, } \uparrow \text { Bax, } \uparrow \text { LC3-II, } \\
\uparrow \text { apoptosis, } \downarrow \text { p-Akt (Thr308 and Ser473), } \\
\downarrow \text { PI3K, } \downarrow \text { mTOR (Ser2448) }\end{array}$ & [95] \\
\hline & In vivo & A549/DTX xenograft & $\downarrow$ Tumor volume, $\downarrow$ Ki-67, $\downarrow$ p-Akt, $\downarrow$ mTOR & {$[95]$} \\
\hline & In vitro & A549 & $\uparrow R O S, \uparrow L C 3 B-I I$ & [137] \\
\hline & In vitro & A549 & $\begin{array}{l}\uparrow \text { Apoptosis, } \uparrow \text { ROS, } \downarrow \text { Sp } 1, \downarrow \text { Sp3, } \downarrow \text { Sp } 4, \\
\downarrow \text { cMyc, } \downarrow \text { EGFR, } \downarrow \text { survivin, } \downarrow \text { cMET }\end{array}$ & [125] \\
\hline & In vitro & A549, NCl-H460 & $\begin{array}{l}\uparrow \text { Apoptosis, } \uparrow \text { Bax, } \uparrow \text { cleaved caspase- } 3 \\
\text { and }-8, \downarrow \text { Bcl- } 2\end{array}$ & [102] \\
\hline & In vivo & A549 xenograft & $\begin{array}{l}\downarrow \text { Tumor volume, } \downarrow \text { tumor weight, } \uparrow \text { Fas, } \\
\uparrow D R 4, \uparrow \text { Bax, } \downarrow \text { Bcl- } 2, \uparrow \text { cleaved caspase-3 } \\
\text { and }-8, \downarrow \text { nuclear } p 50 \text { and p65 }\end{array}$ & [102] \\
\hline & In vitro & A549 & $\uparrow E$-cadherin, $\downarrow$ snail1, $\downarrow$ Twist 1 & [121] \\
\hline & In vitro & A549 & $\begin{array}{l}\text { G1 phase arrest, } \uparrow \text { ROS, } \downarrow \text { cyclin D1, } \\
\downarrow \text { CDK6, } \uparrow p \text {-ERK1/2, } \downarrow p-A k t, \downarrow p-R b, \\
\downarrow N F-k B \text { p65 nuclear translocation, } \downarrow R b, \\
\downarrow \text { CDK4 }\end{array}$ & [91] \\
\hline
\end{tabular}


Table 1. Mechanism of action of PL against different cancers (continued)

\begin{tabular}{|c|c|c|c|c|}
\hline Cancer & In vitro/In vivo & Model & Outcome/Mechanism & References \\
\hline MM & In vitro & $\begin{array}{l}\text { OPM2, MM1R, U266, IM-9, } \\
\text { NCl-H929 }\end{array}$ & $\begin{array}{l}\uparrow \text { Apoptosis, } \uparrow \text { caspase- } 3,-9, \text { or }-8 \text { activity, } \\
\uparrow \text { cyclin } E, \downarrow \text { Bcl- } 2, \uparrow \text { Bax/Bcl- } 2, \uparrow R O S, \\
\downarrow \text { STAT3 activity, } \uparrow p 21, \uparrow p 27, \downarrow c-\text { myc, } \\
\downarrow \text { cyclin } A, \downarrow \text { survivin }\end{array}$ & [110] \\
\hline \multirow[t]{3}{*}{ Prostate cancer } & In vitro & PC-3, DU-145, LNCaP & $\begin{array}{l}\downarrow \text { Proliferation, } \downarrow \text { NF-kB }, \downarrow \text { IL-6, } \downarrow \text { IL-8, } \\
\downarrow \text { MMP-9, } \downarrow \text { invasion, } \downarrow \text { adhesion, } \downarrow \text { ICAM-1 }\end{array}$ & [101] \\
\hline & In vitro & DU-145 & $\begin{array}{l}\downarrow p-S T A T 3^{T y r}-705, \downarrow \text { cyclin A, } \downarrow \text { survivin, } \\
\uparrow \text { cleaved PARP, } \downarrow \text { cell survival, } \uparrow \mathrm{G} 1 / \mathrm{S} \\
\text { arrest, } \uparrow \text { ERK } 1 / 2, \downarrow \mathrm{Bcl}-2\end{array}$ & [111] \\
\hline & In vitro & PC-3 & $\begin{array}{l}\downarrow \text { Akt/mTORC1, } \downarrow \text { GSK-3 } \beta, \downarrow \text { TSC2, } \\
\downarrow \text { p70S6K, } \uparrow \text { LC3-II, } \uparrow \text { autophagy, } \downarrow 4 \text { E-BP1 }\end{array}$ & {$[90]$} \\
\hline \multirow[t]{8}{*}{ Pancreatic cancer } & In vitro & MIAPaCa-2, PANC-1 & $\uparrow$ Cell death, $\uparrow$ ROS & [140] \\
\hline & In vitro & Panc1, L3.6pL & $\uparrow$ Apoptosis, $\uparrow$ ROS, $\downarrow$ Sp $1, \downarrow S p 3, \downarrow S p 4$ & [125] \\
\hline & & & $\downarrow$ cMyc, $\downarrow$ EGFR, $\downarrow$ survivin, $\downarrow$ cMET & \\
\hline & In vitro & PANC-1, MIA PaCa-2 & $\uparrow R O S, \uparrow S O D 1, \uparrow G S T P 1, \uparrow H O-1$ & [85] \\
\hline & In vivo & PANC-1 xenograft & $\downarrow$ Tumor growth, $\downarrow$ Ki67, $\uparrow 8-O H d G$ & [85] \\
\hline & In vitro & PANC-1, AsPC-1, BxPC-3 & $\begin{array}{l}\downarrow c-M y c, \downarrow \text { cyclin } D 1, \downarrow \mathrm{Bcl}-2, \downarrow \mathrm{Bcl}-\mathrm{xL}, \\
\downarrow \text { XIAP, } \downarrow \text { VEGF, } \downarrow \text { MMP-9, } \downarrow \text { NF-KB, } \\
\downarrow \text { survivin, }\end{array}$ & [115] \\
\hline & In vivo & BxPC-3 xenograft & $\begin{array}{l}\downarrow \text { Tumor growth, } \downarrow \text { c-Myc, } \downarrow \text { cyclin D1, } \downarrow \text { Bcl- } \\
2, \downarrow \text { survivin, } \downarrow \text { XIAP, } \downarrow \text { VEGF, } \downarrow \text { MMP-9, } \\
\downarrow \text { NF-kB, } \downarrow \text { Bcl-xL }\end{array}$ & [115] \\
\hline & In vitro & MIA PaCa-2, PANC-1 & $\begin{array}{l}\downarrow \text { GST activity, } \uparrow \text { JNK activation, } \uparrow \text { C-Jun, } \\
\uparrow \mathrm{HMOX} 1, \uparrow \mathrm{HSPA} 1 \mathrm{~A}, \uparrow \mathrm{Myc}, \uparrow \mathrm{CASP} 3, \\
\uparrow \mathrm{PIK} 3 \mathrm{CG}, \downarrow \text { Bcl-2, } \downarrow \text { NF-kB1, } \downarrow \text { AKT3, } \\
\uparrow \text { cleaved caspase- } 3, \uparrow \text { cleaved PARP, } \\
\uparrow \text { apoptosis, } \uparrow A T F-2, \uparrow \text { CDKN1A, } \downarrow p \text {-ERK }\end{array}$ & [139] \\
\hline \multirow[t]{4}{*}{$\mathrm{RCC}$} & In vitro & $786-0$ & $\begin{array}{l}\downarrow \text { Akt/mTORC1, } 1 \text { GSK-3ß, } \downarrow \text { TSC2, } \\
\downarrow \text { p70S6K, } \text { LC3-II, } \downarrow 4 \mathrm{E}-\mathrm{BP} 1\end{array}$ & {$[90]$} \\
\hline & In vitro & $786-0$ & $\begin{array}{l}\uparrow \text { Apoptosis, } \uparrow \text { ROS, } \downarrow \text { Sp } 1, \downarrow \text { Sp3 }, \downarrow \text { Sp4, } \\
\downarrow \text { CMyc, } \downarrow \text { EGFR, } \downarrow \text { survivin }, \downarrow \text { CMET }\end{array}$ & [125] \\
\hline & In vitro & 786-O, PNX0010 & $\begin{array}{l}\downarrow \mathrm{CMET}, \downarrow p-E R K 1 / 2, \downarrow p-S T A T 3, \downarrow p-A k t, \\
\uparrow R O S\end{array}$ & [146] \\
\hline & In vivo & PTX xenograft & $\downarrow$ Tumor growth, $\downarrow$ cMET & [146] \\
\hline Skin cancer & In vitro & A375, A875, B16-F10 & $\begin{array}{l}\text { G2/M phase arrest, } \uparrow \text { apoptosis, } \uparrow \text { cleaved } \\
\text { caspase- } 3, \downarrow \mathrm{Bcl}-2, \uparrow \mathrm{Bax}, \uparrow \mathrm{p}-\mathrm{JNK}, \uparrow \mathrm{ROS}, \\
\uparrow \mathrm{p} 21, \uparrow \mathrm{p} 27\end{array}$ & [141] \\
\hline
\end{tabular}

8-OHdG: 8-hydroxy-2'-deoxyguanosine; ABC-DLBCL: activated B cell-like subtype of diffuse large B cell lymphoma; ATF4: activating transcription factor-4; CCA: cholangiocarcinoma; Cdc: cell division control; CHOP: C/EBP homologous protein; CK18: cytokeratin 18; cMET: hepatocyte growth factor receptor; COX-2: cyclooxygenase-2; DMH: 1,2-dimethylhydrazine; DR4: death receptor 4; DSS: dextran sulfate sodium; DTX: docetaxel-resistant; EGFR: epidermal growth factor receptor; FOXO3A: forkhead box O3A; GST: GSH S-transferase; GSTP1: GST pi 1; HCC: hepatocellular carcinoma; HO-1: heme oxygenase-1; MDA: malondialdehyde; MM: multiple myeloma, MMP-9: matrix metalloproteinases-9; Nrf2: nuclear factorerythroid-2-related factor-2; HK2: hexokinase 2; NQO1: NAD(P)H quinone dehydrogenase 1; p-elF2 $\alpha$ : phosphorylation of eukaryotic initiation factor-2a; PRDX4: peroxiredoxin 4; PTX: paclitaxel; Rb: retinoblastoma; RCC: renal cell carcinoma; SETDB1: SET domain bifurcated histone lysine methyltransferase 1; SOD: superoxide dismutase; SOX2: sex determining region Y-box 2; Sp: specificity protein; TrxR: thioredoxin reductase; VEGF: vascular endothelial growth factor; ZEB1: zinc finger E-box binding homeobox 1; ZO-1: zonula occludens-1

Table 2. Chemosensitizing potential of PL

\begin{tabular}{|c|c|c|c|c|c|}
\hline Drugs & Cancer & $\begin{array}{l}\text { In vitrol } \\
\text { In vivo }\end{array}$ & Model & Mechanism & References \\
\hline Bortezomib & MM & In vitro & $\mathrm{NCl}-\mathrm{H} 929$ & $\uparrow$ Apoptosis, $\downarrow$ p-STAT3 & [110] \\
\hline \multirow[t]{2}{*}{ Cisplatin } & $\mathrm{HNC}$ & In vitro & $\begin{array}{l}\text { AMC-HN2, -HN3, -HN4, -HN6, } \\
\text {-HN7, -HN8, SNU-1041, -1066, } \\
\text {-1076, HN30, HN31, UMSCC1, } \\
\text { 93-VU-147T }\end{array}$ & $\begin{array}{l}\uparrow R O S, \downarrow G S H, \uparrow G S S G, \uparrow P U M A, \\
\uparrow \text { cleaved PARP, } \uparrow p-J N K, \downarrow G S T P 1, \\
\text {-HN9, } \uparrow \text {-p53 (Ser 15), } \uparrow \text { apoptosis }\end{array}$ & [149] \\
\hline & & In vivo & AMC-HN2 \& -HN9, xenograft & $\downarrow$ Tumor growth, $\uparrow p 53, \uparrow$ apoptosis & [149] \\
\hline Doxorubicin & $\begin{array}{l}\text { Prostate } \\
\text { cancer }\end{array}$ & In vitro & DU-145 & $\begin{array}{l}\uparrow \text { Apoptosis, } \uparrow \text { caspase- } 3, \uparrow \text { cleaved } \\
\text { PARP }\end{array}$ & [148] \\
\hline
\end{tabular}


Table 2. Chemosensitizing potential of PL (continued)

\begin{tabular}{|c|c|c|c|c|c|}
\hline Drugs & Cancer & $\begin{array}{l}\text { In vitrol } \\
\text { In vivo }\end{array}$ & Model & Mechanism & References \\
\hline 5-Flurouracil & Oral cancer & In vitro & SAS, CGHNC8 & $\downarrow$ Cell viability, $\downarrow$ survival & [144] \\
\hline \multirow[t]{2}{*}{ Gemcitabine } & $\begin{array}{l}\text { Pancreatic } \\
\text { cancer }\end{array}$ & In vitro & BxPC-3, PANC-1, AsPC-1 & $\uparrow$ Apoptosis, $\downarrow$ NF-kB & [115] \\
\hline & & In vivo & BxPC-3 xenograft & $\downarrow$ Tumor burden, $\uparrow$ apoptosis, $\downarrow$ NF-kB & [115] \\
\hline \multirow[t]{2}{*}{ Oxaliplatin } & $\begin{array}{l}\text { Gastric } \\
\text { cancer }\end{array}$ & In vitro & SGC-7901, AGS, BGC-823 & $\begin{array}{l}\downarrow \text { TrxR1 activity, } \uparrow \text { ROS, } \uparrow \text { apoptosis, } \\
\text { Activation of p38 and JNK signaling } \\
\text { pathways, } \uparrow Y-H 2 A . X\end{array}$ & [147] \\
\hline & & In vivo & SGC-7901 xenograft & $\downarrow$ Tumor growth, $\downarrow$ TrxR1 activity & [147] \\
\hline PTX & $\begin{array}{l}\text { Intestinal } \\
\text { Cancer }\end{array}$ & In vitro & INT-407 and HCT-116 & $\downarrow$ Proliferation & [127] \\
\hline
\end{tabular}

GSSG: GSH disulphide; p: phosphorylated

\section{ABC-DLBCL}

Diffuse large B cell lymphoma (DLBCL) represents the most typical type of non-Hodgkin's lymphoma, and ABC-DLBCL is the most aggressive form of DLBCL, which results in poor 5-year survival of patients $[122,150]$. It was reported that PL significantly induced apoptosis and cell death in ABC-DLBCL cell lines via suppression of NF- $\kappa B$ signaling pathway and modulating the NF- $\mathrm{BB}$-mediated proteins responsible for apoptosis and cell survival such as Bcl-2, survivin, Bax, and p21 [122].

\section{Bladder cancer}

Bladder cancer, one of the most predominant cancers of the urinary tract, occurring most frequently in males than in females, is found to affect around 430,000 people worldwide annually [151]. PL was found to inhibit the proliferation, migration, and invasion of bladder cancer cells in vitro by targeting the F-actin reorganization and modulating the ERK and PKC pathways. It further arrested the cell cycle at the G2/M phase. The results were also confirmed through in vivo studies where PL was demonstrated to inhibit tumor growth and EMT, one of the important hallmarks of cancer [123].

\section{Biliary cancer}

Biliary cancer is one of the most aggressive types of neoplasms, with a very high rate of mortality, poor prognosis, and low 5-year survival rate [152]. PL was reported to show potent anti-proliferative activity against both biliary epithelial tumor cells and gallbladder carcinoma cells in vitro via arresting the cell cycle at the G2/M and G0/G1 phase, respectively. Further, PL induced apoptosis and autophagy in biliary cancer cell lines, which could be attributed to the modulation of the ROS-activated ERK pathway [112].

Another rare type of biliary cancer, CCA, often results in poor diagnosis and prognosis [59, 153]. Studies assessing the efficacy of PL treatment on CCA cell lines have revealed that this compound induced cell cycle arrest at G2/M phase and apoptosis by regulating the expression of different pro- and anti-apoptotic proteins [113]. In addition, this compound increased the levels of intracellular ROS and imparted ROSdepended cell death via stimulation of JNK and ERK levels. Further, the suppression of proteasome activity by PL was also suggested to be responsible for inducing apoptosis [113].

\section{Breast cancer}

Breast cancer is one of the most prevalent cancers worldwide and constitutes the major cause of cancerrelated mortality in females [154-156]. Studies over the years [90, 92, 100, 116, 117, 120, 121, 125, 126] have demonstrated that PL regulated the major processes leading to the development and progression of breast cancer, including cell proliferation, growth, invasion, migration, metastasis, and EMT. An in vitro study has demonstrated that PL treatment induced apoptosis and autophagy in breast cancer cells via modulating the downstream components of the Akt/mTOR signaling pathway [90]. Another study reported that PL suppresses TGF- $\beta$ induced migration, invasion, and EMT in breast cancer cells by reversing the effects of TGF- $\beta$ on the EMT-related protein E-cadherin and modulating the expressions of Snail1 and Twist1 [121]. 
Additionally, PL was found to inhibit proliferation and induce apoptosis in breast cancer cells by modulating the expressions of critical proteins such as topoisomerase II, p53, p21, Bcl-2, Bax, cytochrome c (Cyt C), caspase-3, caspase-7, and caspase-8 [116]. Additionally, studies have also demonstrated that PL suppressed the invasiveness of triple-negative breast cancer cells (TNBC) and inhibited EMT through modulating the expressions of key proteins such as MMPs, ZEB1, Slug, and E-cadherin. Further, it enhanced the expression of the microRNA, miR-200c, loss of which plays a critical role in tumorigenesis [120,124]. Furthermore, PL was found to target the human epidermal growth factor receptor (HER) family in breast cancer, which plays a major role in controlling the intracellular signaling pathways. PL significantly diminished the phosphorylated levels of HER1, HER2, and HER3 via increasing the generation of ROS in breast cancer cells [126]. It was also demonstrated that ROS dependent cytotoxicity exerted by PL could suppress the expression of IKK $\beta$, which resulted in inactivation of the NF-кB signaling pathway and subsequently an upsurge in the levels of p21 mRNA [100]. Additionally, another study reported that PL suppressed SETDB1, which induced the level of caspase-9 dependent-PARP cleavage leading to apoptosis in MCF7 cells. In addition, PL also enhanced the transcriptional activity of FBJ murine osteosarcoma viral oncogene homolog B (FosB), which might also be responsible for PL-induced apoptosis [117].

\section{Cervical cancer}

Cervical cancer is the fourth most prevalent cancer among women, and it constitutes about $4 \%$ of all the malignancies $[157,158]$. PL was shown to induce apoptosis and inhibit cell viability in cervical cancer cell line HeLa. In addition, it was observed that PL upregulated the expression of pro-apoptotic protein Bcl-2-like protein 11 (BIM) and significantly inhibited the Akt signaling pathway, thereby leading to the dephosphorylation of FOXO3A [92]. However, further in-depth studies are required to establish the role of PL in this cancer.

\section{CRC}

The incidence of CRC is increasing globally, and it is also estimated that by 2035 , the percentage of mortality due to CRC will increase by $60-70 \%[50,159,160]$. Numerous studies have demonstrated the efficiency of PL against CRC both in vitro and in vivo. One such study has reported that PL induced cytotoxicity on CRC cells mainly through the suppression of cyclin D1, which was involved in maintaining the tumorigenicity of the CRC cells. PL also negatively regulated the Akt and ERK1/2 signaling pathways, thereby suppressing the levels of $c$-Fos in CRC cells. Another in vivo study by the same group has demonstrated that PL significantly inhibited the tumor growth in the xenograft mouse model of CRC [93]. Further, a study has also proposed that PL inhibited mitogen-activated protein kinase (MAPK)/ERK kinase (MEK) signaling in CRC cells, thereby inducing cell death in a dose and time-dependent manner [114]. Further, PL was shown to significantly inhibit the proliferation of SW-620 CRC cell lines [116]. Moreover, PL was found to induce apoptosis in CRC cells by inhibiting the JNK signaling pathway [133]. In addition, this compound was able to induce cytotoxicity and apoptosis in CRC cells without alerting the expressions of Bax, p21, and p53 [131]. PL was also reported to induce ROS generation in CRC cells and target the GSH anti-oxidant and TrxR systems. Further, enhanced levels of ROS generated by PL led to DNA damage and cell cycle arrest in the CRC cells [129].

The potential of PL was also examined in a DMH/DSS-induced experimental colon cancer model. On PL treatment, a significant improvement in weight and food intake of the mice was observed. In addition, cell cycle arrest at the G2/M phase and induction of apoptosis were observed, which resulted in the reduction of tumor growth. Further, the potential of PL in inhibiting tumor formation was attributed to the inhibition of the Ras/PI3K/Akt/mTOR signaling pathway [130]. This compound was also found to suppress tumor growth in a nude mouse model and induced the restoration of wild-type p53 function [132]. Additionally, administration of PL could significantly alleviate the levels of COX-2, IL-6, $\beta$-catenin, and snail, thereby attenuating inflammation and tumor progression in azoxymethane (AOM)/DSS-induced mouse model of CRC [128]. PL was also found to impart morphological changes and nuclear damage in CRC, which further prompted apoptosis and cell death. Apart from this, PL drastically increased the intracellular levels of ROS, which also resulted in apoptosis, as evident from the modulation in the expression of numerous proteins such 
as Bax, Bcl-2, survivin, p53, and p21 associated with the process. Additionally, PL was found to hamper the migration potential of the CRC cells [127].

\section{Gastric cancer}

Gastric cancer may occur from acute gastritis and is known to be the third prevalent cause of cancer-related mortalities worldwide [161-163]. Over the years, the potential of PL against gastric cancer is demonstrated with the help of numerous pre-clinical studies. For instance, PL was reported to induce the generation of ROS in gastric cancer cells, which resulted in inhibition of cell proliferation and subsequently cell death. Further, induction of GADD45 $\alpha$ was observed upon PL treatment which led to cell cycle arrest in the G2/M phase [119]. It was also suggested that PL might modulate the expression of TrxR1, one of the key anti-oxidant enzymes, both in vitro and in vivo, which caused ROS-mediated apoptosis in gastric cancer cells [135]. Moreover, another study has proposed the anti-cancer potential of PL might be attributed to its ability to inhibit the JAK1,2/STAT3 signaling pathway [109]. Further, PL was found to induce BIM-mediated apoptosis regulated by the significant upregulation of the tumor suppressor and transcription factor FOXO3A [92].

\section{Glioma}

High-grade glioma (HGG) is the commonest type of brain cancer out of the 120 types, which results in a poor prognosis $[136,164]$. PL was shown to interact with the levels of ROS-degrading enzyme PRDX4 and induce ROS generation in HGG cells, which further led to the induction of endoplasmic reticulum (ER) stress and apoptosis [136]. Glioblastoma multiforme (GBM) is the most prevalent and lethal type of glioma with a poor 5-year survival rate [59, 136]. A potent analog of $\mathrm{PL},(E)-N$-(4-fluorobenzyl)-3-(3,4,5-trimethoxyphenyl) acrylamide (NFBTA), showed significant anti-cancer activity against GBM cells. In vitro studies on NFBTA treated GBM cell line U87MG have also reported that this compound is highly selective towards the cancer cells and imparted significant anti-proliferative and apoptotic effects. Further, NFBTA was also involved in modulating the expression of the key factors of the oncogenic signaling pathways such as FOS, RAF1, NFKB1/1A/2, BRAF, PIK3CA/R1, Tumor protein 53 (TP53), phosphatase and tensin homolog (PTEN), Akt1/2, EGFR, dishevelled segment polarity protein 1 (DVL1), and KRAS [134].

\section{Head and neck cancer}

Head and neck cancer (HNC) is a frequently occurring malignancy globally is associated with poor prognosis [165]. In a pre-clinical study, the effects of a combination of PL and p53-reactivation and induction of massive apoptosis-1 (PRIMA-1 ${ }^{\mathrm{Met}}$, also known as APR-246) on HNC cells were evaluated. PRIMA-1 ${ }^{\text {Met }}$ is known to reinstate the DNA-binding ability of mutant p53 and restore the wild-type p53 activity. The combination was found to significantly induce apoptosis and autophagy in HNC cells and reduce tumor growth in animal models and thus could be considered as a novel treatment strategy for HNC [142]. Oral cancer, the commonest form of HNC, causes around 128,000 deaths yearly and is one of the most prevalent in Southern Asia and the Pacific islands $[89,166]$. Several pre-clinical studies have evidenced the potential of PL against oral cancer. For instance, an in vitro study has reported that PL helped in suppressing the stemness of oral cancer cells, an important property needed for tumor maintenance, by modulating the levels of the transcription factors Oct-4, NANOG, SOX2, and CK18. This compound also significantly suppressed the critical hallmarks of cancer such as migration, invasion, and EMT, thereby inhibiting tumor growth both in vitro and in vivo [144]. In addition, another in vitro study has revealed that PL could also bring about senescence via upregulation of p21, which is known to be involved in numerous biological processes, including senescence [145].

\section{HCC}

HCC stands as the fifth most prevalent type of cancer among males and seventh among females $[167,168]$. In vitro studies on liver cancer cell lines have reported that upon treatment with PL, the ROS levels increased significantly, which exerts anti-proliferative effects on these cells. Further, PL treatment led to ROS-mediated apoptosis, G2/M phase cell cycle arrest, and ER stress in the liver cancer cells. Additionally, the effects of PL 
treatment were also evaluated in in vivo models, where a decrease in the tumor progression was observed. The tumor-suppressive role of PL was mainly attributed to its ability to target TrxR1, a key enzyme of the anti-oxidant system, which was found to be highly upregulated in the case of liver cancer [64].

\section{Lung cancer}

Lung cancer is one of the most commonly occurring cancers and has the highest rate of mortality worldwide [168-170]. An in vitro study analyzed the effects of PL in lung cancer cell lines with a modulated expression of profilin-1 (PFN1), one of the actin-binding proteins (ABPs), which plays a critical role in the regulation of cellular migration. It was observed that PL could significantly exert cytotoxic effects on the cancerous cells and its effects were more prominent when the expression of PFN1 was downregulated [143]. Another preclinical study on non-small cell lung carcinoma (NSCLC) cells revealed that PL treatment decreased the levels of HK2, an enzyme of the glycolysis process which was found to be involved in tumor progression. Subsequently, the glycolysis process of the cancerous cells was dysregulated by PL treatment. Further, it was put forth that inhibition of Akt phosphorylation by PL was partially responsible for the inhibition of glycolysis and induction of apoptosis in lung cancer cells. The results were further validated in animal models of lung cancer which presented similar outcomes [94]. Additionally, the efficacy of PL in inducing apoptosis and autophagy in both in vitro and in vivo models of lung cancer was attributed to its role in suppressing the components of the PI3K/Akt/mTOR signaling pathway [95]. Moreover, PL was shown to suppress the activation of Akt in lung cancer cells which further inhibited the expressions of ERK $1 / 2$ and NF- $\mathrm{KB}$ [91].

Another in vitro study has reported that in addition to inducing ROS mediated cytotoxicity in lung cancer cells, PL modulated the expressions of the Sp regulated genes such as cyclin D1, EGFR, hepatocyte growth factor receptor $(H G F R)$, and survivin and also suppressed the transcription factors Sp1, Sp3, and Sp4 [125]. Furthermore, PL was found to act upon the components of the NF- $\mathrm{BB}$ signaling pathway and inhibited tumor progression both in vitro and in vivo [102]. Also, as observed in breast cancer cells, PL was found to be effective in inhibiting TGF- $\beta$-induced EMT and invasion in lung cancer cells. This compound exerted similar activity by reversing the effects of TGF- $\beta$ on the EMT-related protein E-cadherin and interrelating the expressions of Snail1 and Twist1 [121].

PL was also found to impart cytotoxic effects on NSCLC cells compared to the normal lung cells both alone and synergistically when used in combination with another alkaloid, sanguinarine [138]. This compound also induced anti-cancer activity by promoting the levels of ROS and 1B-LC3B-II, an essential protein involved in autophagy. However, PL in combination with gemcitabine enhanced the cytotoxicity but failed to upregulate the levels of ROS and LC3B-II [137].

\section{MM}

MM is a malignancy of the B-cells, characterized by an atypical growth and invasion of plasma cells to the bone marrow [171, 172]. The potential of PL against MM was investigated by an in vitro study where PL was found to exert anti-proliferative and anti-apoptotic effects in MM cells. The anti-apoptotic effects of PL were mediated by its ability to modulate the Fas- and mitochondria-dependent pathways. Following PL treatment, the expression of Bcl-2 was diminished, and an inclination in the Bax/Bcl-2 ratio was observed. Further, activation of the caspase family of proteins was also increased. Moreover, significant inhibition of the STAT3 signaling pathway was also evidenced after PL treatment [110].

\section{Prostate cancer}

Prostate cancer is a very common cancer in men with a high rate of incidence in the Western countries as compared to the Asian population [97, 173, 174]. PL was found to significantly inhibit the activation of NF- $\kappa B$ and modulate the expressions of NF- $\kappa$ B mediated proteins such as IL-6, IL-8, MMP-9, and intercellular adhesion molecule 1 (ICAM-1), thereby suppressing the metastatic potential of the prostate cancer cells [101]. In addition, PL was shown to inactivate the Akt/mTOR signaling via ROS generation, which subsequently induced cell death and autophagy in prostate cancer cells. The same study also evidenced the inhibition of 
tumor growth in a mouse model of prostate cancer by both PL alone and in combination with chloroquine [90]. Moreover, an in vitro study on PL derivatives demonstrated that one of the derivatives, namely CG-06, could suppress the activation of STAT3 by directly binding to it and partly through ROS generation more effectively than PL [111].

\section{Pancreatic cancer}

Pancreatic cancer is a lethal disease with a poor prognosis $[26,175,176]$. A recent study evaluating the effect of PL on pancreatic cancer cells has reported that this compound could induce ferroptosis via ROS generation. The study further displayed that the cytotoxic potential of PL against pancreatic cancer cells was greatly enhanced when used in combination with cotylenin $\mathrm{A}$, a growth regulator, and the commercial drug sulfasalazine [140]. Additionally, Karki et al. [125], who have evaluated the potential of PL in breast and lung cancers, have reported that the compound was effective in pancreatic cancer cells as well, mainly through the suppression of the Sp transcription factors and their regulated genes. Also, PL was found to inhibit cell growth via inducing ROS-mediated DNA damage both in vitro and in vivo models of pancreatic cancer [85]. Furthermore, PL suppressed NF- $\kappa B$ activation, and other NF- $\kappa B$ regulated genes including c-myc, cyclin D1, Bcl-2, Bcl-xL, survivin, XIAP, VEGF, and MMP-9 in pre-clinical models of pancreatic cancer, which led to suppression of cell proliferation and induction apoptosis [115]. Additionally, PL treatment resulted in the activation of the JNK signaling pathway and time-dependent activation of ERK signaling in pancreatic cancer cells, thereby imparting apoptotic cell death [139].

\section{RCC}

RCC is the most common type of kidney tumor, which has a high rate of incidence in men than in women $[177,178]$. Studies on RCC cells have proved that PL could significantly suppress the Akt/mTOR signaling pathway mainly through generating ROS in RCC cells, which subsequently led to cell death and inhibition of critical hallmarks associated with tumor initiation and progression [90]. Furthermore, Karki et al. [125] have evaluated the potential of PL in inhibiting RCC and reported that this compound suppresses the Sp transcription factors and regulated genes. Additionally, PL was shown to inhibit the expression of c-Met through ROS-mediated proteasome independent pathway in RCC cells, which subsequently inhibited the phosphorylated levels of ERK1/2, STAT3, and Akt. The analogs of PL, namely, PL-fluorophenyl (PL-FPh) and PL-Dimer (PL-Di), were further found to impart more prominent anti-tumor effects both in vitro and in vivo as compared to the native form of PL [146].

\section{Skin cancer}

Skin cancer is the most prevalent cancer type among Caucasians, which can be of two types, namely, melanoma and non-melanoma $[179,180]$. The potential of PL was evaluated in melanoma cells, where this compound was found to induce cytotoxicity in a concentration and time-dependent manner. This compound induced ROS generation, which ultimately led to a decline in the mitochondrial membrane potential. Further, PL was shown to modulate the expression of p21, p27, caspases-3, Bax/Bcl-2, and JNK, which are the critical regulators involved in proliferation, cell apoptotic death, and JNK signaling pathway [141].

\section{Chemosensitizing potential of PL}

Chemoresistance stands as the major constraint over using the standard chemotherapeutic agents available for cancer [11,12,14]. Over the years, several studies have evaluated the potential of PL as a potent and affordable anti-cancer drug. PL was found to modulate the key components of the critical signaling pathways which are involved in developing chemoresistance in cancer cells. Thus, the recent focus was driven towards developing PL as a chemosensitizer which sensitized the cancer cells towards the commercially available chemotherapeutics. The following section describes the role of PL in chemosensitizing the cancer cells towards some of the essential drugs. 


\section{Cisplatin}

Cisplatin is a very common drug that is used in the treatment of many cancer types, including ovarian cancer and HNC [181]. However, cisplatin treatment was known to induce chemoresistance in cancer cells. Over the years, numerous studies have suggested that cisplatin resistance could arise due to epigenetic changes, including lesser accumulation of the platinum compounds in the cells, detoxification by GSH conjugates, metallothioneins, and various other antioxidants, rise in the levels of DNA damage repair, changes in the status of DNA-methylation, upregulated expression of chaperones, modulation of microRNA expression, transcription factors and small GTPases, and dysregulation of the apoptosis and EMT pathway [182]. In addition, it was observed that loss or mutation of p53 in HNC is linked to cisplatin resistance due to suppression of senescence [183]. However, a recent study showed that PL was able to reduce the cisplatin resistance in p53 mutant HNC cells both in vitro and in vivo. In vitro, the combination of PL and cisplatin imparted cytotoxicity synergistically and induced ROS generation, and the expression of p53 and p-p53, and cleaved PARP, thereby leading to apoptosis. Similar results were obtained in in vivo studies as well, where significant apoptotic death and inhibition of tumor growth were observed [149].

\section{Doxorubicin}

Doxorubicin, another widely used anti-cancer drug that has been employed for the treatment of a wide variety of cancers such as breast, gastric, lung, lymphoma (Hodgkin's and non-Hodgkin's), MM, ovarian, sarcoma, and thyroid. However, treatment of cancer cells with doxorubicin is known to induce chemoresistance through the modulation of different signaling pathways, non-metabolic pathways, and post-translational modifications [184, 185]. Numerous reports have suggested that carbonyl reductase 1 (CBR1), which results in a declined biotransformation of anthracyclines to lesser active metabolites, might be a key target for the chemosensitizing agents. It was reported that when doxorubicin was used in combination with PL, the formation of the inactive metabolite doxorubicinol (DOXol) was reduced. Further, molecular modeling studies have suggested the interaction between PL and the active sites of CBR1 is similar as reported in the case of the previously studied CBR1 inhibitors, which showed potential chemosensitizing effects. Additionally, PL was evidenced to suppress chemoresistance of prostate cancer cells and sensitize the cancer cells to doxorubicin. When doxorubicin was administered in combination with PL in prostate cancer cells, the effect was synergistic, and the treatment induced apoptosis, as evident from the modulated expression of the apoptotic proteins such as caspase- 3 and PARP. These effects might be attributed to the ability of PL to bind with and inhibit CBR1 $[148,186]$.

\section{5-Fluorouracil}

5-Fluorouracil (5-FU) has been in use since 1957 and is still the third most frequently used anti-cancer drug for the treatment of solid tumors in the world [187, 188]. It is a very common drug that is used in the treatment of oral cancer. However, over the years, studies have evinced that extensive use of the drug has led to the development of chemoresistance of oral cancer cells. Studies have shown that high levels of CSC markers in cancer cells also result in the development of chemoresistance in cancer cells [189]. PL was found to significantly inhibit the stem cell properties in oral cancer cells, which might have contributed to the chemosensitizing potential of PL. Thus, PL, when used in combination with 5-FU, helped in enhancing the cytotoxic effects by reducing the cell viability and survival of oral cancer cells [144].

\section{Gemcitabine}

Gemcitabine is the first-line therapy for pancreatic cancer. However, in the majority of the patients, it induces chemoresistance and becomes ineffective due to the activation of the NF- $\mathrm{BB}$ pathway, which is predominantly implicated in the development of chemoresistance in this cancer [26]. An in vitro study on pancreatic cancer cells has evidenced that gemcitabine, when used in combination with PL, imparted more prominent anticancer effects mediated through blockage of NF- $\mathrm{B}$ activation. Furthermore, in in vivo studies, the combined treatment was found to be more effective in reducing tumor growth compared to gemcitabine alone [115]. 


\section{Oxaliplatin}

Oxaliplatin is a platinum-based chemotherapeutic drug that is used for the treatment of various cancers, including colorectal and gastric cancers [147, 190]. However, chemoresistance and severe side-effects associated with the use of this drug limit its efficacy [191, 192]. TrxR1, a flavoenzyme, is found to be overexpressed in various types of cancers and is associated with improved tumor growth and chemoresistance. It was observed that PL helped in sensitizing gastric cancer cells towards oxaliplatin mainly by enhancing the generation of ROS via suppressing the activation of TrxR1, thereby inducing apoptosis. This combination also resulted in the activation of the p38 and JNK cell signaling pathways in vitro and in vivo [147].

\section{PTX}

PTX or taxol is one of the widely used anti-cancer drugs used commonly for the treatment of breast, lung, and ovarian cancers, etc. [193]. Though the drug is found to be very effective, extensive use of it was often found to result in chemoresistance of cancer cells. However, the exact mechanism of PTX associated chemoresistance is still not precise [194]. A recent study showed that PL sensitized intestinal cancer cells to PTX by effectively inhibiting the proliferation of the cancer cells. Additionally, it was elucidated that PL might have activated the SMAD4 pathway, thereby improving the chemotherapeutic effect of the cancer cells by stimulating p21 and its downstream pathways resulting in apoptosis [127].

\section{Radiosensitizing potential of PL}

Radiotherapy is a widely used treatment modality for cancer patients and is considered to have an added advantage due to its localized application. However, over the years, the development of radioresistance due to alterations in the signaling pathways associated with radiosensitivity, tumor heterogeneity and cancer stem cells have limited the use of radiotherapy and resulted in poor prognosis in the patients [195]. Therefore, the application of radiosensitizers was found to be an effective method for improving the radiosensitivity of cancer cells and minimizing the adverse effects of radiotherapy on the adjacent normal cells [196].

Small molecule radiosensitizers, including oxygen, active phytochemicals, hypoxia-specific cytotoxins, and agents, modulate the cell signal pathways involved in radioresistance [197]. Oxygen is considered to be a potential radiosensitizer as the hypoxic tumor microenvironment is one of the major obstacles of radiotherapy. Administration of oxygen leads to the formation of peroxide in the hypoxic tumor microenvironment resulting in permanent cellular and DNA damage [198]. Additionally, nonmetallic nanomaterials such as carbon nanotubes and selenium nanoparticles also enhance the radiosensitivity of cancer cells via ROS activation and cellular DNA damage [197]. In this context, PL was reported to show similar effects in breast cancer cells. It was found that when PL was used even at a very low concentration of $2.5 \mu \mathrm{mol} / \mathrm{L}$ in combination with X-ray radiation (6 Gy), the level of radiation-induced generation of ROS in cancer cells was improved, and the rate of apoptosis was also enhanced [199]. PL (0-15 $\mu \mathrm{M})$ was further reported to enhance the radiosensitivity of CRC cells mediated via ROS production, where the radio response of the cancer cells was improved in a concentration-dependent manner. Additionally, in animal models, tumor growth was delayed when PL $(2.4 \mathrm{mg} / \mathrm{kg})$ was administered in combination with a single (8 Gy) and fractionated radiations (3 Gy $\times 3$ ) [129].

RAD001, an inhibitor of mTOR, is an important radiosensitizer used in traditional medical radiotherapy [200]. A study had reported that when oral cancer cells SCC4 and SCC25 were exposed to radiation (0-8 Gy) in combination RAD001 (30 or $300 \mathrm{nM}$ for $1 \mathrm{~h}$ ), radiosensitivity of the cells increased significantly in 14 days [200]. Interestingly, in a study, oral cancer cell lines SAS and CGHNC8 were subjected to PL, radiation, and a combination of both, and after 5-7 days, it was observed that the radiation sensitivity of the cells treated with the combination was enhanced by $47.5 \%$ and $25.63 \%$, respectively [144]. Thus, it is evident that when used in combination with PL, very low intensity of radiation is found to be effective in cancer cells which is extremely important because radiation therapy is associated with numerous side effects such as mutation, alopecia, myelosuppression, etc. Further, PL attenuated the mRNA levels of the cancer stem 
cells associated markers such as SOX2, NANOG, and Oct-4, ultimately inhibiting cancer stem cell properties which is one of the major obstacles to radiation therapy [144].

Lately, research has been focused on exploring the radiosensitizing efficiency of phytochemicals, such as curcumin, and resveratrol. For instance, the radiosensitizing activity of curcumin and resveratrol was found to be associated with the modulation of the transcription factor, NF- $\kappa \mathrm{B}$, which is known to be involved in the radioresistance of cancer cells [201,202]. Another study evaluating the radiosensitization activity of curcumin on in vivo model of CRC reported that when curcumin $(1 \mathrm{~g} / \mathrm{kg}$; twice daily) was administered in combination with radiation ( $4 \mathrm{~Gy}$, twice weekly; given $1 \mathrm{~h}$ after curcumin), the tumor size is reduced significantly. In this study, the chemosensitizing potential was also attributed to its ability to inhibit the NF-кB signaling pathway [203]. Similarly, BKM120 (0.25-1 $\mu \mathrm{M})$ and BEZ235 (0-10 nM) enhance the radiosensitivity of cancer cells by targeting the PI3K-Akt/mTOR pathway [204, 205]. Multiple lines of evidence have suggested that PL treatment significantly modulated the NF- $\mathrm{KB}$ and PI3K/Akt/mTOR signaling pathway in different types of cancers, which provides a hint to explore more regarding the radiosensitizing potential of PL.

\section{Pharmacokinetics and bioavailability of PL}

PL is a hydrophobic drug and thereby exhibits very poor solubility in water. Therefore, despite its immense potential as an anti-cancer drug, its low solubility decreases bioavailability and limits its therapeutic efficacy [206, 207]. However, the co-administration of PL with docetaxel enhanced the bioavailability of docetaxel in Sprague-Dawley rats by 1.68-fold, thus acting as a bio enhancer [208]. A study reported that the plasma concentrations of $\mathrm{PL}$, post-administration $(50 \mathrm{mg} / \mathrm{kg})$ in rats, were found to be $1511.9 \mathrm{ng} / \mathrm{mL}$, $418.2 \mathrm{ng} / \mathrm{mL}$, and $41.9 \mathrm{ng} / \mathrm{mL}$ PL at $30 \mathrm{~min}, 3 \mathrm{~h}$, and $24 \mathrm{~h}$, respectively [209]. Due to the low bioavailability of PL, the development of novel drug delivery systems is essential for the enhancement of effectiveness in vivo [210]. Drug carriers, such as hydrogels, liposomes, microspheres, and nanoparticles, are efficient means of improving the solubility, cellular uptake, and bioavailability of a drug. In addition, these drug delivery systems are also associated with tumor-targeted drug release [207].

Chitosan is a biocompatible natural polymer, and chitosan-based nanoparticles are a safe and efficient drug delivery system. A study showed that PL encapsulated chitosan-based nanoparticles exhibited a high potential for tumor-targeted drug release and showed cytotoxicity against gastric cancer cells by increasing the intracellular ROS. Moreover, it increased the solubility and bioavailability of PL [207]. Another study reported that the encapsulation of PL in chitosan- and fucoidan-based nanoparticles also enhanced its bioavailability and solubility. Furthermore, these nanoparticles induced cytotoxicity against prostate cancer cells by inducing oxidative stress via the excessive formation of ROS [211]. Nanoemulsions are also known to enhance the stability, solubility, and bioavailability of a drug. Pharmacokinetic analysis showed that the orally administered PL-loaded nanoemulsion was rapidly absorbed and slowly eliminated compared to the pure form of the drug. This improved the oral bioavailability of the PL-loaded nanoemulsion by approximately 1.5 -fold as compared to the pure form. However, a study showed that the bioavailability of PL following oral administration at $5 \mathrm{mg} / \mathrm{kg}$ and $10 \mathrm{mg} / \mathrm{kg}$ were $76.39 \%$ and $50.08 \%$, respectively [61]. Hence, further studies need to be undertaken in order to elucidate the pharmacokinetic profile of this pleiotropic natural compound.

\section{Toxicity profile of PL}

Analysis of the toxicity profile of a compound is a pre-requisite for developing it as an anti-cancer drug. The non-toxic nature of PL is evidenced by a number of pre-clinical studies. For instance, a study evaluating the effect of paclitaxel and PL nanoformulation on a xenograft model of HCC has evidenced that the combination diminished the toxicity imparted by the native form of the drugs on the adjacent tissues of the tumor [212]. Additionally, the effect of PL on the normal function of the kidney and liver was evaluated by assessing the serum levels of alanine aminotransferase (ALT), urea, aspartate aminotransferase (AST), and creatinine. It was observed that PL reversed the levels of these enzymes, which was shown to be escalated with DMH + DSS treatment, thus showing that PL does not have any adverse effect on the normal functioning of the liver and kidney. Also, on investigating liver sections, no significant alterations were found, thus confirming that PL 
is not associated with hepatotoxicity [130]. Also, another study showed that though PL exerted significant cytotoxicity on lung cancer cells, it did not hamper the growth of normal lung epithelial cells [138]. Further, toxicological studies also revealed that the oral administration of a PL-nanoemulsion did not exhibit any toxicity in mice for 60 days. However, PL loaded nanoemulsions $(10 \mathrm{mg} / \mathrm{kg})$ induced potent anti-tumor activity against the in vivo xenograft model of melanoma [206].

\section{Conclusion and future prospects}

PL, the amide alkaloid isolated from the roots and fruits of long pepper, is a potential compound for the prevention and treatment of many different cancers. Since the discovery of its structure in 1968, many researchers have been successful in isolating and synthesizing the compound in laboratories following different approaches from the commercially available precursors. A wide variety of PL derivatives such as L50377 have also been synthesized, mainly exploiting the anti-cancer property exhibiting moiety 3,4,5-trimethoxybenzyl present in PL. PL is also combined with metal complexes such as $\left[\mathrm{RuCl}_{2}(\mathrm{~N}-\mathrm{N})\right.$ (P-P)] and 1,4-bis(diphenylphosphino)butane, $\mathrm{PtCl}_{2}\left(\mathrm{PPh}_{3}\right)_{2}$, cis-[PtCl(PIP-OH) $\left.\left(\mathrm{PPh}_{3}\right)_{2}\right] \mathrm{PF}_{6}$ to enhance its therapeutic effects.

PL and its derivatives were reported to exhibit diverse biological activities, including anti-arthritic, anti-asthmatic, anti-diabetic, anti-epileptic, anti-inflammatory, anti-microbial, anti-oxidant, anti-stress, antitumor, anti-ulcer, and immunomodulatory activities, which encouraged researchers to explore more about the pharmacological effects of this compound. The anti-cancer property of PL against different types of cancers has been studied in detail in in vitro and in vivo settings. The ability of PL to modulate the important cell signaling pathways such as PI3K/Akt/ mTOR, NF- $\mathrm{KB}$, JAK/ STAT3, and ERK suggests that this compound is effective in modulating the important hallmarks of cancer, including cell survival, proliferation, invasion, migration, EMT, metastases, and angiogenesis. The multi-targeted and pleiotropic nature of PL suggested that it might also be able to regulate complex phenomena such as chemoresistance and radioresistance, which are the major hindrances towards the current treatment modalities. Further, researchers must focus on exploring the effects of PL in different experimental models for a particular cancer type and in conducting more studies in ex vivo and clinical settings.

Recently, the focus was driven towards developing PL as a chemosensitizer and radiosensitizer which sensitized the cancer cells towards the commercially available chemotherapeutics including cisplatin, doxorubicin, 5-FU, gemcitabine, oxaliplatin, and PTX, and ionization/X-ray radiation. PL was found to sensitize the cancer cells to chemotherapeutics and radiation by acting on the cell signaling pathways and genes associated with chemo and radioresistance, inhibiting the biotransformation of the drugs into less active metabolites, and suppressing the properties of cancer stem cells. It was also reported that PL exhibited anti-cancer effects at a very low concentration which tends to reduce the chances of toxicity of the adjacent normal cells, organs, and adverse side-effects. In fact, PL was reported to impart hepatoprotective and cardioprotective effects. Therefore, this compound might be used as an adjuvant in combination with the standard chemotherapeutics to relieve the side effects caused by them to some extent.

The main hindrance towards developing PL as a standard chemotherapeutic is its hydrophobic nature contributing to its low bioavailability. However, studies have evidenced that PL enhanced the bioavailability of docetaxel when used in combination and thus acted as a bio enhancer. Therefore, drug carriers, such as hydrogels, liposomes, microspheres, and nanoparticles formulations can be adapted for enhancing the bioavailability of PL. It was also found that PL-loaded nanoemulsion showed a better pharmacokinetic profile compared to the pure form of this drug.

Although PL has shown immense potential in the prevention and treatment of different types of cancers; however, some studies must be conducted as a pre-requisite to validate the pre-clinical studies and developing it as a clinical chemotherapeutic drug are mentioned below:

- The chemopreventive effects of PL should be evaluated in different experimental models of a particular cancer type.

- Cytotoxicity studies of the compound in different organs should be conducted. 
- Molecular markers should be developed to determine the efficacy of PL in randomized multicentered clinical trials.

- The bioavailability of PL and its metabolic and toxicity profile should be studied in detail in humans.

- Effective bioformulations of PL that are designed for sustained release should be developed.

Hence, proper attention should be given to conducting such studies of this compound to develop it as a potential anti-cancer drug. Further, it is worth mentioning that the safe nature of PL strengthens the evaluation of the therapeutic effects of this drug in clinical trials in the future.

\section{Abbreviations}

ABC-DLBCL: activated B cell-like subtype of diffuse large B cell lymphoma

Akt: protein kinase $B$

Bax: B-cell lymphoma 2 associated $\mathrm{X}$ apoptosis regulator

Bcl-2: B-cell lymphoma 2

Bcl-xL: B-cell lymphoma-extra-large

CBR1: carbonyl reductase 1

CCA: cholangiocarcinoma

CDK: cyclin-dependent kinase

CHOP: C/EBP homologous protein

cMET: hepatocyte growth factor receptor

CRC: colorectal cancer

DLBCL: diffuse large B cell lymphoma

DMH: 1,2-dimethylhydrazine

DSS: dextran sulfate sodium

EGFR: epidermal growth factor receptor

ERK: extracellular signal-regulated kinases

FOX03A: forkhead box 03A

GADD45 $\alpha$ : growth arrest and DNA-damage-inducible, alpha

GBM: glioblastoma multiforme

GSH: glutathione

GSTP1: glutathione S-transferase pi 1

HCC: hepatocellular carcinoma

HER: human epidermal growth factor receptor

HK2: hexokinase 2

HNC: head and neck cancer

HO-1: heme oxygenase-1

IL: interleukin

JAK: Janus kinase

JNK: c-Jun $\mathrm{N}$-terminal kinase

LC3: microtubule-associated protein 1 light chain 3

MDA: malondialdehyde

MM: multiple myeloma

MMP-9: matrix metalloproteinases-9

mTOR: mammalian target of rapamycin 
NFBTA: (E)- $N$-(4-fluorobenzyl)-3-(3,4,5-trimethoxyphenyl) acrylamide

NF-кB: nuclear factor-kappa B

PARP: poly (ADP-ribose) polymerase

PCNA: proliferating cell nuclear antigen

p-eIF $2 \alpha$ : phosphorylation of eukaryotic initiation factor- $2 \alpha$

PI3K: phosphoinositide 3-kinases

PL: piperlongumine

PTX: paclitaxel

RCC: renal cell carcinoma

ROS: reactive oxygen species

SOX2: sex determining region Y-box 2

Sp: specificity protein

STAT3: signal transducer and activator of transcription 3

TGF- $\beta$ : transforming growth factor-beta

TrxR: thioredoxin reductase

VEGF: vascular endothelial growth factor

XIAP: X-linked inhibitor of apoptosis protein

ZEB1: zinc finger E-box binding homeobox 1

\section{Declarations}

\section{Acknowledgements}

The authors acknowledge DBT-AIST International Center for Translational and Environmental Research (DAICENTER) for providing support to carry out the present work.

\section{Author contributions}

ABK contributed to the study design, conceptualisation, supervision and review editing. DP and VR performed bibliographic search. DP and SG contributed to original manuscript. DP and VR contributed to table preparation and proofreading. AK and DP performed artwork. DP, SG, UDD, EV and KKT contributed to review editing. DP, SG, AK and UDD contributed to proofreading.

\section{Conflicts of interest}

The authors express no conflict of interest.

Ethical approval

Not applicable.

\section{Consent to participate}

Not applicable.

\section{Consent to publication}

Not applicable.

Availability of data and materials

Not applicable.

\section{Funding}

This project was supported by DBT-AIST International Center for Translational and Environmental 
Research (DAICENTER). The funder had no role in study design, data collection and analysis, decision to publish, or preparation of the manuscript.

\section{Copyright}

(C) The Author(s) 2021.

\section{References}

1. Banik K, Harsha C, Bordoloi D, Lalduhsaki Sailo B, Sethi G, Leong HC, et al. Therapeutic potential of gambogic acid, a caged xanthone, to target cancer. Cancer Lett. 2018;416:75-86.

2. Banik K, Ranaware AM, Deshpande V, Nalawade SP, Padmavathi G, Bordoloi D, et al. Honokiol for cancer therapeutics: a traditional medicine that can modulate multiple oncogenic targets. Pharmacol Res. 2019;144:192-209.

3. Banik K, Ranaware AM, Harsha C, Nitesh T, Girisa S, Deshpande V, et al. Piceatannol: a natural stilbene for the prevention and treatment of cancer. Pharmacol Res. 2020;153:104635.

4. Girisa S, Shabnam B, Monisha J, Fan L, Halim CE, Arfuso F, et al. Potential of zerumbone as an anti-cancer agent. Molecules. 2019;24:734.

5. Khwairakpam AD, Bordoloi D, Thakur KK, Monisha J, Arfuso F, Sethi G, et al. Possible use of Punica granatum (Pomegranate) in cancer therapy. Pharmacol Res. 2018;133:53-64.

6. Ranaware AM, Banik K, Deshpande V, Padmavathi G, Roy NK, Sethi G, et al. Magnolol: a neolignan from the magnolia family for the prevention and treatment of cancer. Int J Mol Sci. 2018;19:2362.

7. Roy NK, Deka A, Bordoloi D, Mishra S, Kumar AP, Sethi G, et al. The potential role of boswellic acids in cancer prevention and treatment. Cancer Lett. 2016;377:74-86.

8. Sailo BL, Banik K, Girisa S, Bordoloi D, Fan L, Halim CE, et al. FBXW7 in cancer: what has been unraveled thus far? Cancers (Basel). 2019;11:246.

9. Sailo BL, Banik K, Padmavathi G, Javadi M, Bordoloi D, Kunnumakkara AB. Tocotrienols: the promising analogues of vitamin E for cancer therapeutics. Pharmacol Res. 2018;130:259-72.

10. Shabnam B, Padmavathi G, Banik K, Girisa S, Monisha J, Sethi G, et al. Sorcin a potential molecular target for cancer therapy. Transl Oncol. 2018;11:1379-89.

11. Bordoloi D, Roy NK, Monisha J, Padmavathi G, Kunnumakkara AB. Multi-targeted agents in cancer cell chemosensitization: what we learnt from curcumin thus far. Recent Pat Anticancer Drug Discov. 2016;11:67-97.

12. Bordoloi D, Sailo BL, Manteghi N, Padmavathi G, Kunnumakkara AB. Introduction and basic concepts of cancer. In: Kunnumakkara AB, Bordoloi D, Monisha J, editors. Cancer cell chemoresistance and chemosensitization. Singapore: World Scientific; 2018. pp. 1-13.

13. Bray F, Ferlay J, Soerjomataram I, Siegel RL, Torre LA, Jemal A. Global cancer statistics 2018: GLOBOCAN estimates of incidence and mortality worldwide for 36 cancers in 185 countries. CA Cancer J Clin. 2018;68:394-424.

14. Khatoon E, Banik K, Harsha C, Sailo BL, Thakur KK, Khwairakpam AD, et al. Phytochemicals in cancer cell chemosensitization: current knowledge and future perspectives. Semin Cancer Biol. 2020;S1044579X:30150-4.

15. Singh AK, Roy NK, Bordoloi D, Padmavathi G, Banik K, Khwairakpam AD, et al. Orai-1 and Orai-2 regulate oral cancer cell migration and colonisation by suppressing Akt/mTOR/NF-kappaB signalling. Life Sci. 2020;261:118372.

16. Ferlay J, Colombet M, Soerjomataram I, Parkin DM, Pineros M, Znaor A, et al. Cancer statistics for the year 2020: an overview. Int J Cancer. 2021; [Epub ahead of print].

17. Anand P, Kunnumakkara AB, Sundaram C, Harikumar KB, Tharakan ST, Lai OS, et al. Cancer is a preventable disease that requires major lifestyle changes. Pharm Res. 2008;25:2097-116. 
18. Aggarwal BB, Sethi G, Baladandayuthapani V, Krishnan S, Shishodia S. Targeting cell signaling pathways for drug discovery: an old lock needs a new key. J Cell Biochem. 2007;102:580-92.

19. Shanmugam MK, Lee JH, Chai EZ, Kanchi MM, Kar S, Arfuso F, et al. Cancer prevention and therapy through the modulation of transcription factors by bioactive natural compounds. Semin Cancer Biol. 2016;40-41:35-47.

20. Kunnumakkara AB, Bordoloi D, Sailo BL, Roy NK, Thakur KK, Banik K, et al. Cancer drug development: the missing links. Exp Biol Med (Maywood). 2019;244:663-89.

21. Henamayee S, Banik K, Sailo BL, Shabnam B, Harsha C, Srilakshmi S, et al. Therapeutic emergence of rhein as a potential anticancer drug: a review of its molecular targets and anticancer properties. Molecules. 2020;25:2278.

22. Kirtonia A, Gala K, Fernandes SG, Pandya G, Pandey AK, Sethi G, et al. Repurposing of drugs: an attractive pharmacological strategy for cancer therapeutics. Semin Cancer Biol. 2021;68:258-78.

23. Kunnumakkara AB. Anticancer properties of fruits and vegetables. Singapore: World Scientific; 2015.

24. Nair AS, Shishodia S, Ahn KS, Kunnumakkara AB, Sethi G, Aggarwal BB. Deguelin, an Akt inhibitor, suppresses IkappaBalpha kinase activation leading to suppression of NF-kappaB-regulated gene expression, potentiation of apoptosis, and inhibition of cellular invasion. J Immunol. 2006;177:5612-22.

25. Khanna D, Sethi G, Ahn KS, Pandey MK, Kunnumakkara AB, Sung B, et al. Natural products as a gold mine for arthritis treatment. Curr Opin Pharmacol. 2007;7:344-51.

26. Kunnumakkara AB, Guha S, Krishnan S, Diagaradjane P, Gelovani J, Aggarwal BB. Curcumin potentiates antitumor activity of gemcitabine in an orthotopic model of pancreatic cancer through suppression of proliferation, angiogenesis, and inhibition of nuclear factor-kappaB-regulated gene products. Cancer Res. 2007;67:3853-61.

27. Kunnumakkara AB, Nair AS, Ahn KS, Pandey MK, Yi Z, Liu M, et al. Gossypin, a pentahydroxy glucosyl flavone, inhibits the transforming growth factor beta-activated kinase-1-mediated NF-kappaB activation pathway, leading to potentiation of apoptosis, suppression of invasion, and abrogation of osteoclastogenesis. Blood. 2007;109:5112-21.

28. Kunnumakkara AB, Sung B, Ravindran J, Diagaradjane P, Deorukhkar A, Dey S, et al. Zyflamend suppresses growth and sensitizes human pancreatic tumors to gemcitabine in an orthotopic mouse model through modulation of multiple targets. Int J Cancer. 2012;131:E292-303.

29. Quinn BJ, Dallos M, Kitagawa H, Kunnumakkara AB, Memmott RM, Hollander MC, et al. Inhibition of lung tumorigenesis by metformin is associated with decreased plasma IGF-I and diminished receptor tyrosine kinase signaling. Cancer Prev Res (Phila). 2013;6:801-10.

30. Padmavathi G, Rathnakaram SR, Monisha J, Bordoloi D, Roy NK, Kunnumakkara AB. Potential of butein, a tetrahydroxychalcone to obliterate cancer. Phytomedicine. 2015;22:1163-71.

31. Padmavathi G, Roy NK, Bordoloi D, Arfuso F, Mishra S, Sethi G, et al. Butein in health and disease: a comprehensive review. Phytomedicine. 2017;25:118-27.

32. Kunnumakkara AB, Banik K, Bordoloi D, Harsha C, Sailo BL, Padmavathi G, et al. Googling the guggul (commiphora and boswellia) for prevention of chronic diseases. Front Pharmacol. 2018;9:686.

33. Bordoloi D, Monisha J, Roy NK, Padmavathi G, Banik K, Harsha C, et al. An investigation on the therapeutic potential of butein, a tretrahydroxychalcone against human oral squamous cell carcinoma. Asian Pac J Cancer Prev. 2019;20:3437-46.

34. Roy NK, Parama D, Banik K, Bordoloi D, Devi AK, Thakur KK, et al. An update on pharmacological potential of boswellic acids against chronic diseases. Int J Mol Sci. 2019;20:4101.

35. Zhang YJ, Gan RY, Li S, Zhou Y, Li AN, Xu DP, et al. Antioxidant phytochemicals for the prevention and treatment of chronic diseases. Molecules. 2015;20:21138-56.

36. Kunnumakkara AB, Chung JG, Koca C, Dey S. Mint and its constituents. In: Kunnumakkara AB, Aggarwal BB, editors. Molecular targets and therapeutic uses of spices. 2009; pp. 373-401. 
37. Kunnumakkara AB, Sung B, Ravindran J, Diagaradjane P, Deorukhkar A, Dey S, et al. $\gamma$-Tocotrienol inhibits pancreatic tumors and sensitizes them to gemcitabine treatment by modulating the inflammatory microenvironment. Cancer Res. 2010;70:8695-705.

38. Gutierrez RMP, Gonzalez AMN, Hoyo-Vadillo C. Alkaloids from piper: a review of its phytochemistry and pharmacology. Mini Rev Med Chem. 2013;13:163-93.

39. Palombo EA. Phytochemicals from traditional medicinal plants used in the treatment of diarrhoea: modes of action and effects on intestinal function. Phytother Res. 2006;20:717-24.

40. Howes MJ, Perry E. The role of phytochemicals in the treatment and prevention of dementia. Drugs Aging. 2011;28:439-68.

41. Ahmed SA, Parama D, Daimari E, Girisa S, Banik K, Harsha C, et al. Rationalizing the therapeutic potential of apigenin against cancer. Life Sci. 2021;267:118814.

42. Aswathy M, Banik K, Parama D, Sasikumar P, Harsha C, Joseph AG, et al. Exploring the cytotoxic effects of the extracts and bioactive triterpenoids from dillenia indica against oral squamous cell carcinoma: a scientific interpretation and validation of indigenous knowledge. ACS Pharmacol Transl Sci. 2021; 4:834-47.

43. Babu BH, Jayram HN, Nair MG, Ajaikumar KB, Padikkala J. Free radical scavenging, antitumor and anticarcinogenic activity of gossypin. J Exp Clin Cancer Res. 2003;22:581-9.

44. Aggarwal BB, Kunnumakkara AB, Harikumar KB, Tharakan ST, Sung B, Anand P. Potential of spicederived phytochemicals for cancer prevention. Planta Med. 2008;74:1560-9.

45. Choudhury B, Kandimalla R, Bharali R, Monisha J, Kunnumakara AB, Kalita K, et al. Anticancer activity of garcinia morella on T-cell murine lymphoma via apoptotic induction. Front Pharmacol. 2016;7:3.

46. Monisha J, Padmavathi G, Roy NK, Deka A, Bordoloi D, Anip A, et al. NF- $\kappa B$ blockers gifted by mother nature: prospectives in Cancer Cell Chemosensitization. Curr Pharm Des. 2016;22:4173-200.

47. Maruthanila VL, Elancheran R, Kunnumakkara AB, Kabilan S, Kotoky J. Recent development of targeted approaches for the treatment of breast cancer. Breast Cancer. 2017;24:191-219.

48. Kunnumakkara AB, Sailo BL, Banik K, Harsha C, Prasad S, Gupta SC, et al. Chronic diseases, inflammation, and spices: how are they linked? J Transl Med. 2018;16:14.

49. Awasthee N, Rai V, Chava S, Nallasamy P, Kunnumakkara AB, Bishayee A, et al. Targeting IkappaappaB kinases for cancer therapy. Semin Cancer Biol. 2019;56:12-24.

50. Buhrmann C, Popper B, Kunnumakkara AB, Aggarwal BB, Shakibaei M. Evidence that calebin A, a component of Curcuma Longa suppresses NF-B mediated proliferation, invasion and metastasis of human colorectal cancer induced by TNF- $\beta$ (Lymphotoxin). Nutrients. 2019;11:2904.

51. Nair A, Amalraj A, Jacob J, Kunnumakkara AB, Gopi S. Non-curcuminoids from turmeric and their potential in cancer therapy and anticancer drug delivery formulations. Biomolecules. 2019;9:13.

52. Shu L, Cheung KL, Khor TO, Chen C, Kong AN. Phytochemicals: cancer chemoprevention and suppression of tumor onset and metastasis. Cancer Metastasis Rev. 2010;29:483-502.

53. Dias DA, Urban S, Roessner U. A historical overview of natural products in drug discovery. Metabolites. 2012;2:303-36.

54. Newman DJ, Cragg GM. Natural products as sources of new drugs from 1981 to 2014. J Nat Prod. 2016;79:629-61.

55. Thomas D, Govindhan S, Baiju EC, Padmavathi G, Kunnumakkara AB, Padikkala J. Cyperus rotundus L. prevents non-steroidal anti-inflammatory drug-induced gastric mucosal damage by inhibiting oxidative stress. J Basic Clin Physiol Pharmacol. 2015;26:485-90.

56. Harsha C, Banik K, Bordoloi D, Kunnumakkara AB. Antiulcer properties of fruits and vegetables: a mechanism based perspective. Food Chem Toxicol. 2017;108:104-19. 
57. Khwairakpam AD, Damayenti YD, Deka A, Monisha J, Roy NK, Padmavathi G, et al. Acorus calamus: a bioreserve of medicinal values. J Basic Clin Physiol Pharmacol. 2018;292:107-22.

58. Devi Khwairakpam A, Monisha J, Roy NK, Bordoloi D, Padmavathi G, Banik K, et al. Vietnamese coriander inhibits cell proliferation, survival and migration via suppression of Akt/mTOR pathway in oral squamous cell carcinoma. J Basic Clin Physiol Pharmacol. 2019;31:20190162.

59. Parama D, Boruah M, Yachna K, Rana V, Banik K, Harsha C, et al. Diosgenin, a steroidal saponin, and its analogs: effective therapies against different chronic diseases. Life Sci. 2020;260:118182.

60. Chatterjee A, Dutta CP. Alkaloids of Piper longum Linn. I. Structure and synthesis of piperlongumine and piperlonguminine. Tetrahedron. 1967;23:1769-81.

61. Bezerra DP, Pessoa C, de Moraes MO, Saker-Neto N, Silveira ER, Costa-Lotufo LV. Overview of the therapeutic potential of piplartine (piperlongumine). Eur J Pharm Sci. 2013;48:453-63.

62. Tripathi SK, Biswal BK. Piperlongumine, a potent anticancer phytotherapeutic: perspectives on contemporary status and future possibilities as an anticancer agent. Pharmacol Res. 2020;156:104772.

63. Yadav V, Krishnan A, Vohora D. A systematic review on Piper longum L.: bridging traditional knowledge and pharmacological evidence for future translational research. J Ethnopharmacol. 2020;247:112255.

64. Zhang $\mathrm{Q}$, Chen $\mathrm{W}$, Lv X, Weng $\mathrm{Q}$ Chen $\mathrm{M}$, Cui R, et al. Piperlongumine, a novel TrxR1 inhibitor, induces apoptosis in hepatocellular carcinoma cells by ROS-mediated ER stress. Front Pharmacol. 2019;10:1180.

65. Joshi K, Panara K, Nishteswar K, Chaudhary S. Cultivation and pharmacological profiles of root of Piper longum Linn. Pharma Science Monitor. 2013;4:3617-27.

66. Choudhary N, Singh V. A census of $P$. longum's phytochemicals and their network pharmacological evaluation for identifying novel drug-like molecules against various diseases, with a special focus on neurological disorders. PLoS One. 2018;13:e0191006.

67. Yan WJ, Wang Q, Yuan CH, Wang F, Ji Y, Dai F, et al. Designing piperlongumine-directed anticancer agents by an electrophilicity-based prooxidant strategy: a mechanistic investigation. Free Radic Biol Med. 2016;97:109-23.

68. Lad NP, Kulkarni S, Sharma R, Mascarenhas M, Kulkarni MR, Pandit SS. Piperlongumine derived cyclic sulfonamides (sultams): synthesis and in vitro exploration for therapeutic potential against HeLa cancer cell lines. Eur J Med Chem. 2017;126:870-8.

69. He K, Xu H, Wang T, Li X, Guo B, Li D, et al. An improved synthesis of piperlongumine and the preliminary imaging evaluation on tumor targeting. J Radioanal Nucl Chem. 2020;324:489-96.

70. Sun LD, Wang F, Dai F, Wang YH, Lin D, Zhou B. Development and mechanism investigation of a new piperlongumine derivative as a potent anti-inflammatory agent. Biochem Pharmacol. 2015;95:156-69.

71. Han LC, Stanley PA, Wood PJ, Sharma P, Kuruppu AI, Bradshaw TD, et al. Horner-Wadsworth-Emmons approach to piperlongumine analogues with potent anti-cancer activity. Org Biomol Chem. 2016;14:7585-93.

72. Li Q, Chen L, Dong Z, Zhao Y, Deng H, Wu J, et al. Piperlongumine analogue L50377 induces pyroptosis via ROS mediated NF-kappaB suppression in non-small-cell lung cancer. Chem Biol Interact. 2019;313:108820.

73. D'Sousa Costa CO, Araujo Neto JH, Baliza IRS, Dias RB, Valverde LF, Vidal MTA, et al. Novel piplartinecontaining ruthenium complexes: synthesis, cell growth inhibition, apoptosis induction and ROS production on HCT116 cells. Oncotarget. 2017;8:104367-92.

74. Oliveira MS, Barbosa MIF, de Souza TB, Moreira DRM, Martins FT, Villarreal W, et al. A novel platinum complex containing a piplartine derivative exhibits enhanced cytotoxicity, causes oxidative stress and triggers apoptotic cell death by ERK/p38 pathway in human acute promyelocytic leukemia HL-60 cells. Redox Biol. 2019;20:182-94. 
75. Baliza IRS, Silva SLR, Santos LS, Neto JHA, Dias RB, Sales CBS, et al. Ruthenium complexes with piplartine cause apoptosis through MAPK signaling by a p53-dependent pathway in human colon carcinoma cells and inhibit tumor development in a xenograft model. Front Oncol. 2019;9:582.

76. Gurumurthy P, Vijayalatha S, Sumathy A, Asokan M, Naseema M. Hepatoprotective effect of aqueous extract of Piper longum and piperine when administered with antitubercular drugs. Bioscan. 2012; 7:661-3.

77. Khushbu C, Lalkrishna P, Roshni S, Virendra K, Dhaval M, Timir P. Effect of Piper longum Linn on histopathological and biochemical changes in isoproterenol induced myocardial infarction in rats. Res J Pharm Biol Chem Sci. 2010;1:759-66.

78. Lee SE, Park BS, Huh TL, Lee EW, Yum JH. Proteomic evaluation on antiplatelet activity of piperlongumine derived from Piper longum. Mol cell Toxicol. 2010;6:295-303.

79. Rao VR, Muthenna P, Shankaraiah G, Akileshwari C, Babu KH, Suresh G, et al. Synthesis and biological evaluation of new piplartine analogues as potent aldose reductase inhibitors (ARIs). Eur J Med Chem. 2012;57:344-61.

80. Son DJ, Kim SY, Han SS, Kim CW, Kumar S, Park BS, et al. Piperlongumine inhibits atherosclerotic plaque formation and vascular smooth muscle cell proliferation by suppressing PDGF receptor signaling. Biochem Biophys Res Commun. 2012;427:349-54.

81. Felipe FCB, Sousa Filho JT, de Oliveira Souza LE, Silveira JA, de Andrade Uchoa DE, Silveira ER, et al. Piplartine, an amide alkaloid from Piper tuberculatum, presents anxiolytic and antidepressant effects in mice. Phytomedicine. 2007;14:605-12.

82. Mgbeahuruike EE, Stålnacke M, Vuorela H, Holm Y. Antimicrobial and synergistic effects of commercial piperine and piperlongumine in combination with conventional antimicrobials. Antibiotics. 2019;8:55.

83. Niu M, Xu X, Shen Y, Yao Y, Qiao J, Zhu F, et al. Piperlongumine is a novel nuclear export inhibitor with potent anticancer activity. Chem Biol Interact. 2015;237:66-72.

84. Zhang Z, Wang F, Du C, Guo H, Ma L, Liu X, et al. BRM/SMARCA2 promotes the proliferation and chemoresistance of pancreatic cancer cells by targeting JAK2/STAT3 signaling. Cancer Lett. 2017;402:213-24.

85. Dhillon H, Chikara S, Reindl KM. Piperlongumine induces pancreatic cancer cell death by enhancing reactive oxygen species and DNA damage. Toxicol Rep. 2014;1:309-18.

86. Sethi G, Ahn KS, Sung B, Kunnumakkara AB, Chaturvedi MM, Aggarwal BB. SH-5, an AKT inhibitor potentiates apoptosis and inhibits invasion through the suppression of anti-apoptotic, proliferative and metastatic gene products regulated by IkappaBalpha kinase activation. Biochem Pharmacol. 2008;76:1404-16.

87. Roy NK, Bordoloi D, Monisha J, Padmavathi G, Kotoky J, Golla R, et al. Specific targeting of Akt kinase isoforms: taking the precise path for prevention and treatment of cancer. Curr Drug Targets. 2017;18:421-35.

88. Roy NK, Monisha J, Padmavathi G, Lalhruaitluanga H, Kumar NS, Singh AK, et al. Isoform-specific role of Akt in oral squamous cell carcinoma. Biomolecules. 2019;9:253.

89. Harsha C, Banik K, Ang HL, Girisa S, Vikkurthi R, Parama D, et al. Targeting AKT/mTOR in oral cancer: mechanisms and advances in clinical trials. Int J Mol Sci. 2020;21:3285.

90. Makhov P, Golovine K, Teper E, Kutikov A, Mehrazin R, Corcoran A, et al. Piperlongumine promotes autophagy via inhibition of Akt/mTOR signalling and mediates cancer cell death. Br J Cancer. 2014;110:899-907.

91. Seok JS, Jeong CH, Petriello MC, Seo HG, Yoo H, Hong K, et al. Piperlongumine decreases cell proliferation and the expression of cell cycle-associated proteins by inhibiting Akt pathway in human lung cancer cells. Food Chem Toxicol. 2018;111:9-18. 
92. Liu Z, Shi Z, Lin J, Zhao S, Hao M, Xu J, et al. Piperlongumine-induced nuclear translocation of the FOXO3A transcription factor triggers BIM-mediated apoptosis in cancer cells. Biochem Pharmacol. 2019;163:101-10.

93. Gao F, Zhou L, Li M, Liu W, Yang S, Li W. Inhibition of ERKs/Akt-mediated c-Fos expression is required for piperlongumine-induced Cyclin D1 downregulation and tumor suppression in colorectal cancer cells. Onco Targets Ther. 2020;13:5591-603.

94. Zhou L, Li M, Yu X, Gao F, Li W. Repression of hexokinases II-mediated glycolysis contributes to Piperlongumine-induced tumor suppression in non-small cell lung cancer cells. Int J Biol Sci. 2019;15:826-37.

95. Wang F, Mao Y, You Q, Hua D, Cai D. Piperlongumine induces apoptosis and autophagy in human lung cancer cells through inhibition of PI3K/Akt/mTOR pathway. Int J Immunopathol Pharmacol. 2015;28:362-73.

96. Garg AK, Jhingran A, Klopp AH, Aggarwal BB, Kunnumakkara AB, Broadus RR, et al. Expression of nuclear transcription factor kappa $B$ in locally advanced human cervical cancer treated with definitive chemoradiation. Int J Radiat Oncol Biol Phys. 2010;78:1331-6.

97. Heymach JV, Shackleford TJ, Tran HT, Yoo SY, Do KA, Wergin M, et al. Effect of low-fat diets on plasma levels of NF-kappaB-regulated inflammatory cytokines and angiogenic factors in men with prostate cancer. Cancer Prev Res (Phila). 2011;4:1590-8.

98. Monisha J, Roy NK, Bordoloi D, Kumar A, Golla R, Kotoky J, et al. Nuclear factor kappa B: a potential target to persecute head and neck cancer. Curr Drug Targets. 2017;18:232-53.

99. Kunnumakkara AB, Shabnam B, Girisa S, Harsha C, Banik K, Devi TB, et al. Inflammation, NF- $\mathrm{kB}$, and chronic diseases: how are they linked? Crit Rev Immunol. 2020;40:1-39.

100. Jeong CH, Ryu H, Kim DH, Cheng WN, Yoon JE, Kang S, et al. Piperlongumine induces cell cycle arrest via reactive oxygen species accumulation and IKK $\beta$ suppression in human breast cancer cells. Antioxidants (Basel). 2019;8:553.

101. Ginzburg S, Golovine KV, Makhov PB, Uzzo RG, Kutikov A, Kolenko VM. Piperlongumine inhibits NFkappaB activity and attenuates aggressive growth characteristics of prostate cancer cells. Prostate. 2014;74:177-86.

102. Zheng J, Son DJ, Gu SM, Woo JR, Ham YW, Lee HP, et al. Piperlongumine inhibits lung tumor growth via inhibition of nuclear factor kappa B signaling pathway. Sci Rep. 2016;6:26357.

103. Aggarwal BB, Kunnumakkara AB. Molecular targets and therapeutic uses of spices. Singapore: World Scientific; 2009.

104. Rawlings JS, Rosler KM, Harrison DA. The JAK/STAT signaling pathway. J Cell Sci. 2004;117:1281-3.

105. Bhutani M, Pathak AK, Nair AS, Kunnumakkara AB, Guha S, Sethi G, et al. Capsaicin is a novel blocker of constitutive and interleukin-6-inducible STAT3 activation. Clin Cancer Res. 2007;13:3024-32.

106. Spitzner M, Ebner R, Wolff HA, Ghadimi BM, Wienands J, Grade M. STAT3: a novel molecular mediator of resistance to chemoradiotherapy. Cancers (Basel). 2014;6:1986-2011.

107. Khanna P, Chua PJ, Bay BH, Baeg GH. The JAK/STAT signaling cascade in gastric carcinoma (review). Int J Oncol. 2015;47:1617-26.

108. Mullen M, Gonzalez-Perez RR. Leptin-induced JAK/STAT signaling and cancer growth. Vaccines (Basel). 2016;4:26.

109. Song B, Zhan H, Bian Q, Gu J. Piperlongumine inhibits gastric cancer cells via suppression of the JAK1,2/ STAT3 signaling pathway. Mol Med Rep. 2016;13:4475-80.

110. Yao Y, Sun Y, Shi M, Xia D, Zhao K, Zeng L, et al. Piperlongumine induces apoptosis and reduces bortezomib resistance by inhibiting STAT3 in multiple myeloma cells. Oncotarget. 2016;7:73497-508. 
111. Kim YH, Yoon YJ, Lee YJ, Kim CH, Lee S, Choung DH, et al. Piperlongumine derivative, CG-06, inhibits STAT3 activity by direct binding to STAT3 and regulating the reactive oxygen species in DU145 prostate carcinoma cells. Bioorg Med Chem Lett. 2018;28:2566-72.

112. Chen SY, Huang HY, Lin HP, Fang CY. Piperlongumine induces autophagy in biliary cancer cells via reactive oxygen species-activated Erk signaling pathway. Int J Mol Med. 2019;44:1687-96.

113. Thongsom S, Suginta W, Lee KJ, Choe H, Talabnin C. Piperlongumine induces G2/M phase arrest and apoptosis in cholangiocarcinoma cells through the ROS-JNK-ERK signaling pathway. Apoptosis. 2017;22:1473-84.

114. Randhawa H, Kibble K, Zeng H, Moyer MP, Reindl KM. Activation of ERK signaling and induction of colon cancer cell death by piperlongumine. Toxicol In vitro. 2013;27:1626-33.

115. Wang Y, Wu X, Zhou Y, Jiang H, Pan S, Sun B. Piperlongumine suppresses growth and sensitizes pancreatic tumors to gemcitabine in a xenograft mouse model by modulating the NF-kappa B pathway. Cancer Prev Res (Phila). 2016;9:234-44.

116. Sriwiriyajan S, Sukpondma Y, Srisawat T, Madla S, Graidist P. (-)-Kusunokinin and piperloguminine from Piper nigrum: an alternative option to treat breast cancer. Biomed Pharmacother. 2017;92:732-43.

117. Park JA, Na HH, Jin HO, Kim KC. Increased expression of FosB through reactive oxygen species accumulation functions as pro-apoptotic protein in Piperlongumine treated MCF7 breast cancer cells. Mol Cells. 2019;42:884-92.

118. Tanida I, Ueno T, Kominami E. Human light chain 3/MAP1LC3B is cleaved at its carboxyl-terminal Met121 to expose Gly120 for lipidation and targeting to autophagosomal membranes. J Biol Chem. 2004;279:47704-10.

119. Duan C, Zhang B, Deng C, Cao Y, Zhou F, Wu L, et al. Piperlongumine induces gastric cancer cell apoptosis and G2/M cell cycle arrest both in vitro and in vivo. Tumour Biol. 2016;37:10793-804.

120. Delaney LM, Farias N, Ghassemi Rad J, Fernando W, Annan H, Hoskin DW. The natural alkaloid Piperlongumine inhibits metastatic activity and epithelial-to-mesenchymal transition of triple-negative mammary carcinoma cells. Nutr Cancer. 2020:1-14.

121. Park MJ, Lee DE, Shim MK, Jang EH, Lee JK, Jeong SY, et al. Piperlongumine inhibits TGF-beta-induced epithelial-to-mesenchymal transition by modulating the expression of E-cadherin, Snail1, and Twist1. Eur J Pharmacol. 2017;812:243-9.

122. Niu M, Shen Y, Xu X, Yao Y, Fu C, Yan Z, et al. Piperlongumine selectively suppresses ABC-DLBCL through inhibition of NF-kappaB p65 subunit nuclear import. Biochem Biophys Res Commun. 2015;462:326-31.

123. Liu D, Qiu XY, Wu X, Hu DX, Li CY, Yu SB, et al. Piperlongumine suppresses bladder cancer invasion via inhibiting epithelial mesenchymal transition and F-actin reorganization. Biochem Biophys Res Commun. 2017;494:165-72.

124. Ljepoja B, Garcia-Roman J, Sommer AK, Frohlich T, Arnold GJ, Wagner E, et al. A proteomic analysis of an in vitro knock-out of miR-200c. Sci Rep. 2018;8:6927.

125. Karki K, Hedrick E, Kasiappan R, Jin UH, Safe S. Piperlongumine induces reactive oxygen species (ROS)-dependent downregulation of specificity protein transcription factors. Cancer Prev Res (Phila). 2017;10:467-77.

126. Jin HO, Park JA, Kim HA, Chang YH, Hong YJ, Park IC, et al. Piperlongumine downregulates the expression of HER family in breast cancer cells. Biochem Biophys Res Commun. 2017;486:1083-9.

127. Rawat L, Hegde H, Hoti SL, Nayak V. Piperlongumine induces ROS mediated cell death and synergizes paclitaxel in human intestinal cancer cells. Biomed Pharmacother. 2020;128:110243.

128. Huang JR, Wang ST, Wei MN, Liu K, Fu JW, Xing ZH, et al. Piperlongumine alleviates mouse colitis and colitis-associated colorectal cancer. Front Pharmacol. 2020;11:586885. 
129. Wang H, Jiang H, Corbet C, de Mey S, Law K, Gevaert T, et al. Piperlongumine increases sensitivity of colorectal cancer cells to radiation: involvement of ROS production via dual inhibition of glutathione and thioredoxin systems. Cancer Lett. 2019;450:42-52.

130. Kumar S, Agnihotri N. Piperlongumine, a piper alkaloid targets Ras/PI3K/Akt/mTOR signaling axis to inhibit tumor cell growth and proliferation in DMH/DSS induced experimental colon cancer. Biomed Pharmacother. 2019;109:1462-77.

131. DA Silva Machado F, Munari FM, Scariot FJ, Echeverrigaray S, Aguzzoli C, Pich CT, et al. Piperlongumine induces apoptosis in colorectal cancer HCT 116 cells independent of bax, p21 and p53 status. Anticancer Res. 2018;38:6231-6.

132. Basak D, Punganuru SR, Srivenugopal KS. Piperlongumine exerts cytotoxic effects against cancer cells with mutant $\mathrm{p} 53$ proteins at least in part by restoring the biological functions of the tumor suppressor. Int J Oncol. 2016;48:1426-36.

133. Li W, Wen C, Bai H, Wang X, Zhang X, Huang L, et al. JNK signaling pathway is involved in piperlonguminemediated apoptosis in human colorectal cancer HCT116 cells. Oncol Lett. 2015;10:709-15.

134. Turkez H, Nobrega FRD, Ozdemir O, Bezerra Filho C, Almeida RN, Tejera E, et al. NFBTA: a potent cytotoxic agent against glioblastoma. Molecules. 2019;24:2411.

135. Zou P, Xia Y, Ji J, Chen W, Zhang J, Chen X, et al. Piperlongumine as a direct TrxR1 inhibitor with suppressive activity against gastric cancer. Cancer Lett. 2016;375:114-26.

136. Kim TH, Song J, Kim SH, Parikh AK, Mo X, Palanichamy K, et al. Piperlongumine treatment inactivates peroxiredoxin 4, exacerbates ER stress, and preferentially kills high-grade glioma cells. Neuro Oncol. 2014;16:1354-64.

137. Ye W, Huang Q, Tang T, Qin G. Synergistic effects of piperlongumine and gemcitabine against KRAS mutant lung cancer. Tumori. 2020;107:119-24.

138. Halas-Wisniewska M, Zielinska W, Izdebska M, Grzanka A. The synergistic effect of Piperlongumine and sanguinarine on the non-small lung cancer. Molecules. 2020;2:3045.

139. Mohammad J, Singh RR, Riggle C, Haugrud B, Abdalla MY, Reindl KM. JNK inhibition blocks piperlongumine-induced cell death and transcriptional activation of heme oxygenase- 1 in pancreatic cancer cells. Apoptosis. 2019;24:730-44.

140. Yamaguchi Y, Kasukabe T, Kumakura S. Piperlongumine rapidly induces the death of human pancreatic cancer cells mainly through the induction of ferroptosis. Int J Oncol. 2018;52:1011-22.

141. Song X, Gao T, Lei Q, Zhang L, Yao Y, Xiong J. Piperlongumine induces apoptosis in human melanoma cells via reactive oxygen species mediated mitochondria disruption. Nutr Cancer. 2018;70:502-11.

142. Hang W, Yin ZX, Liu G, Zeng Q, Shen XF, Sun QH, et al. Piperlongumine and p53-reactivator APR-246 selectively induce cell death in HNSCC by targeting GSTP1. Oncogene. 2018;37:3384-98.

143. Gagat M, Halas-Wisniewska M, Zielinska W, Izdebska M, Grzanka D, Grzanka A. The effect of piperlongumine on endothelial and lung adenocarcinoma cells with regulated expression of profilin-1. Onco Targets Ther. 2018;11:8275-92.

144. Chen YJ, Kuo CC, Ting LL, Lu LS, Lu YC, Cheng AJ, et al. Piperlongumine inhibits cancer stem cell properties and regulates multiple malignant phenotypes in oral cancer. Oncol Lett. 2018;15:1789-98.

145. Chen SY, Liu GH, Chao WY, Shi CS, Lin CY, Lim YP, et al. Piperlongumine suppresses proliferation of human oral squamous cell carcinoma through cell cycle arrest, apoptosis and senescence. Int J Mol Sci. 2016;17:616.

146. Golovine K, Makhov P, Naito S, Raiyani H, Tomaszewski J, Mehrazin R, et al. Piperlongumine and its analogs down-regulate expression of c-Met in renal cell carcinoma. Cancer Biol Ther. 2015;16:743-9.

147. Zhang P, Shi L, Zhang T, Hong L, He W, Cao P, et al. Piperlongumine potentiates the antitumor efficacy of oxaliplatin through ROS induction in gastric cancer cells. Cell Oncol (Dordr). 2019;42:847-60. 
148. Piska K, Koczurkiewicz P, Wnuk D, Karnas E, Bucki A, Wojcik-Pszczola K, et al. Synergistic anticancer activity of doxorubicin and piperlongumine on DU-145 prostate cancer cells-the involvement of carbonyl reductase 1 inhibition. Chem Biol Interact. 2019;300:40-8.

149. Roh JL, Kim EH, Park JY, Kim JW, Kwon M, Lee BH. Piperlongumine selectively kills cancer cells and increases cisplatin antitumor activity in head and neck cancer. Oncotarget. 2014;5:9227-38.

150. Davis RE, Brown KD, Siebenlist U, Staudt LM. Constitutive nuclear factor kappaB activity is required for survival of activated B cell-like diffuse large B cell lymphoma cells. J Exp Med. 2001;194:1861-74.

151. Roy NK, Sharma A, Singh AK, Bordoloi D, Sailo BL, Monisha J, et al. Bladder cancer: chemoresistance and chemosensitization. In: Cancer cell chemoresistance and chemosensitization. Singapore: World Scientific; 2018. pp. 51-80.

152. Oneda E, Abu Hilal M, Zaniboni A. Biliary tract cancer: current medical treatment strategies. Cancers (Basel). 2020;12:1237.

153. Grunnet M, Mau-Sorensen M. Serum tumor markers in bile duct cancer-a review. Biomarkers. 2014;19:437-43.

154. Kumar P, Bolshette NB, Jamdade VS, Mundhe NA, Thakur KK, Saikia KK, et al. Breast cancer status in India: an overview. Biomed Prev Nutr. 2013;3:177-83.

155. Thakur KK, Bordoloi D, Kunnumakkara AB. Alarming burden of triple-negative breast cancer in India. Clin Breast Cancer. 2018;18:e393-9.

156. Daimary UD, Parama D, Rana V, Banik K, Kumar A, Harsha C, et al. Emerging roles of cardamonin, a multitargeted nutraceutical in the prevention and treatment of chronic diseases. Curr Res Pharmacol Drug Discovery. 2021;2:100008.

157. Banik K, Sailo BL, Thakur KK, Jaiswal A, Monisha J, Bordoloi D, et al. Potential of different chemosensitizers to overcome chemoresistance in cervical cancer. In: Cancer cell chemoresistance and chemosensitization. Singapore: World Scientific; 2018. pp. 163-79.

158. Torre LA, Bray F, Siegel RL, Ferlay J, Lortet-Tieulent J, Jemal A. Global cancer statistics, 2012. CA Cancer J Clin. 2015;65:87-108.

159. Kunnumakkara AB, Guha S, Aggarwal BB. Curcumin and colorectal cancer: add spice to your life. Curr Colorectal Cancer Rep. 2009;5:5.

160. Araghi M, Soerjomataram I, Jenkins M, Brierley J, Morris E, Bray F, et al. Global trends in colorectal cancer mortality: projections to the year 2035. Int J Cancer. 2019;144:2992-3000.

161. Choudhary H, Bordoloi D, Prakash J, Manteghi N, Padmavathi G, Monisha J, et al. Different chemosensitization approaches in gastric cancer. In: cancer cell chemoresistance and chemosensitization. Singapore: World Scientific; 2018. pp. 267-319.

162. Ferlay J, Soerjomataram I, Dikshit R, Eser S, Mathers C, Rebelo M, et al. Cancer incidence and mortality worldwide: sources, methods and major patterns in GLOBOCAN 2012. Int J Cancer. 2015;136:E359-86.

163. Gupta SC, Kunnumakkara AB, Aggarwal S, Aggarwal BB. Inflammation, a double-edge sword for cancer and other age-related diseases. Front Immunol. 2018;9:2160.

164. Khwairakpam AD, Monisha J, Banik K, Choudhary H, Sharma A, Bordoloi D, et al. Chemoresistance in brain cancer and different chemosensitization approaches. In: cancer cell chemoresistance and chemosensitization. Singapore: World Scientific; 2018. pp. 107-27.

165. Thakur KK, Bordoloi D, Prakash J, Monisha J, Roy NK, Kunnumakkara AB. Different chemosensitization approaches for the effective management of HNSCC. In: cancer cell chemoresistance and chemosensitization. Singapore: World Scientific; 2018. pp. 399-423.

166. Monisha J, Roy NK, Padmavathi G, Banik K, Bordoloi D, Khwairakpam AD, et al. NGAL is downregulated in oral squamous cell carcinoma and leads to increased survival, proliferation, migration and chemoresistance. Cancers (Basel). 2018;10:228. 
167. Singh AK, Roy NK, Anip A, Banik K, Monisha J, Bordoloi D, et al. Different methods to inhibit chemoresistance in hepatocellular carcinoma. In: cancer cell chemoresistance and chemosensitization. Singapore: World Scientific; 2018. pp. 373-98.

168. Sung H, Ferlay J, Siegel RL, Laversanne M, Soerjomataram I, Jemal A, et al. Global cancer statistics 2020: GLOBOCAN estimates of incidence and mortality worldwide for 36 cancers in 185 countries. CA Cancer J Clin. 2021;71:209-49.

169. Bordoloi D, Banik K, Padmavathi G, Vikkurthi R, Harsha C, Roy NK, et al. TIPE2 induced the proliferation, survival, and migration of lung cancer cells through modulation of Akt/mTOR/NF-kappaB signaling cascade. Biomolecules. 2019;9:836.

170. Bordoloi D, Banik K, Vikkurthi R, Thakur KK, Padmavathi G, Sailo BL, et al. Inflection of Akt/mTOR/STAT-3 cascade in TNF-alpha induced protein 8 mediated human lung carcinogenesis. Life Sci. 2020;262:118475.

171. Sung B, Kunnumakkara AB, Sethi G, Anand P, Guha S, Aggarwal BB. Curcumin circumvents chemoresistance in vitro and potentiates the effect of thalidomide and bortezomib against human multiple myeloma in nude mice model. Mol Cancer Ther. 2009;8:959-70.

172. Thakur KK, Bolshette NB, Trandafir C, Jamdade VS, Istrate A, Gogoi R, et al. Role of toll-like receptors in multiple myeloma and recent advances. Exp Hematol. 2015;43:158-67.

173. Kurahashi N, Sasazuki S, Iwasaki M, Inoue M, Tsugane S; JPHC Study Group. Green tea consumption and prostate cancer risk in Japanese men: a prospective study. Am J Epidemiol. 2008;167:71-7.

174. Muralimanoharan SB, Kunnumakkara AB, Shylesh B, Kulkarni KH, Haiyan X, Ming H, et al. Butanol fraction containing berberine or related compound from nexrutine inhibits NFkappaB signaling and induces apoptosis in prostate cancer cells. Prostate. 2009;69:494-504.

175. Dhillon N, Aggarwal BB, Newman RA, Wolff RA, Kunnumakkara AB, Abbruzzese JL, et al. Curcumin and pancreatic cancer: phase II clinical trial experience. J Clin Oncol. 2007;25 Suppl 18:4599.

176. Verma A, Guha S, Diagaradjane P, Kunnumakkara AB, Sanguino AM, Lopez-Berestein G, et al. Therapeutic significance of elevated tissue transglutaminase expression in pancreatic cancer. Clin Cancer Res. 2008;14:2476-83.

177. Sailo BL, Bordoloi D, Banik K, Khwairakpam AD, Roy NK, Prakash J, et al. Therapeutic strategies for chemosensitization of renal cancer. In: cancer cell chemoresistance and chemosensitization. Singapore: World Scientific; 2018. pp. 615-39.

178. Kashyap MK, Kumar A, Emelianenko N, Kashyap A, Kaushik R, Huang R, et al. Biochemical and molecular markers in renal cell carcinoma: an update and future prospects. Biomarkers. 2005;10:258-94.

179. Monisha J, Roy NK, Sharma A, Banik K, Padmavathi G, Bordoloi D, et al. Chemoresistance and chemosensitization in melanoma. In: cancer cell chemoresistance and chemosensitization. Singapore: World Scientific; 2018. pp. 479-527.

180. Linares MA, Zakaria A, Nizran P. Skin cancer. Prim Care. 2015;42:645-59.

181. Dasari S, Tchounwou PB. Cisplatin in cancer therapy: molecular mechanisms of action. Eur J Pharmacol. 2014;740:364-78.

182. Shen DW, Pouliot LM, Hall MD, Gottesman MM. Cisplatin resistance: a cellular self-defense mechanism resulting from multiple epigenetic and genetic changes. Pharmacol Rev. 2012;64:706-21.

183. Gadhikar MA, Sciuto MR, Alves MV, Pickering CR, Osman AA, Neskey DM, et al. Chk1/2 inhibition overcomes the cisplatin resistance of head and neck cancer cells secondary to the loss of functional p53. Mol Cancer Ther. 2013;12:1860-73.

184. Micallef I, Baron B. Doxorubicin: an overview of the anti-cancer and chemoresistance mechanisms. Ann Clin Toxicol 2020;3:1031.

185. Thorn CF, Oshiro C, Marsh S, Hernandez-Boussard T, McLeod H, Klein TE, et al. Doxorubicin pathways: pharmacodynamics and adverse effects. Pharmacogenet Genomics. 2011;21:440-6. 
186. Arai Y, Endo S, Miyagi N, Abe N, Miura T, Nishinaka T, et al. Structure-activity relationship of flavonoids as potent inhibitors of carbonyl reductase 1 (CBR1). Fitoterapia. 2015;101:51-6.

187. Zhang N, Yin Y, Xu SJ, Chen WS. 5-Fluorouracil: mechanisms of resistance and reversal strategies. Molecules. 2008;13:1551-69.

188. Sara JD, Kaur J, Khodadadi R, Rehman M, Lobo R, Chakrabarti S, et al. 5-fluorouracil and cardiotoxicity: a review. Ther Adv Med Oncol. 2018;10:1758835918780140.

189. Khan IN, Al-Karim S, Bora RS, Chaudhary AG, Saini KS. Cancer stem cells: a challenging paradigm for designing targeted drug therapies. Drug Discov Today. 2015;20:1205-16.

190. Alcindor T, Beauger N. Oxaliplatin: a review in the era of molecularly targeted therapy. Curr Oncol. 2011;18:18-25.

191. Gamelin E, Gamelin L, Bossi L, QuasthoffS. Clinical aspects and molecular basis of oxaliplatin neurotoxicity: current management and development of preventive measures. Semin Oncol. 2002;5 Suppl 15:21-33.

192. Bang YJ, Kim YW, Yang HK, Chung HC, Park YK, Lee KH, et al. Adjuvant capecitabine and oxaliplatin for gastric cancer after D2 gastrectomy (CLASSIC): a phase 3 open-label, randomised controlled trial. Lancet. 2012;379:315-21.

193. Zhang D, Yang R, Wang S, Dong Z. Paclitaxel: new uses for an old drug. Drug Des Devel Ther. 2014;8:279-84.

194. Di Michele M, Della Corte A, Cicchillitti L, Del Boccio P, Urbani A, Ferlini C, et al. A proteomic approach to paclitaxel chemoresistance in ovarian cancer cell lines. Biochim Biophys Acta. 2009;1794:225-36.

195. Tang L, Wei F, Wu Y, He Y, Shi L, Xiong F, et al. Role of metabolism in cancer cell radioresistance and radiosensitization methods. J Exp Clin Cancer Res. 2018;37:87.

196. Gong L, Zhang Y, Liu C, Zhang M, Han S. Application of radiosensitizers in cancer radiotherapy. Int J Nanomedicine. 2021;16:1083-102.

197. Wang H, Mu X, He H, Zhang XD. Cancer radiosensitizers. Trends Pharmacol Sci. 2018;39:24-48.

198. Oronsky BT, Knox SJ, Scicinski J. Six degrees of separation: the oxygen effect in the development of radiosensitizers. Transl Oncol. 2011;4:189-98.

199. Yao JX, Yao ZF, Li ZF, Liu YB. Radio-sensitization by Piper longumine of human breast adenoma MDAMB-231 cells in vitro. Asian Pac J Cancer Prev. 2014;15:3211-7.

200. Yu CC, Hung SK, Liao HF, Lee CC, Lin HY, Lai HC, et al. RAD001 enhances the radiosensitivity of SCC4 oral cancer cells by inducing cell cycle arrest at the G2/M checkpoint. Anticancer Res. 2014;34:2927-35.

201. Aggarwal BB. Nuclear factor-kappaB: the enemy within. Cancer Cell. 2004;6:203-8.

202. Liao HF, Kuo CD, Yang YC, Lin CP, Tai HC, Chen YY, et al. Resveratrol enhances radiosensitivity of human non-small cell lung cancer NCI-H838 cells accompanied by inhibition of nuclear factor-kappa B activation. J Radiat Res. 2005;46:387-93.

203. Kunnumakkara AB, Diagaradjane P, Guha S, Deorukhkar A, Shentu S, Aggarwal BB, et al. Curcumin sensitizes human colorectal cancer xenografts in nude mice to gamma-radiation by targeting nuclear factor-kappaB-regulated gene products. Clin Cancer Res. 2008;14:2128-36.

204. Liu WL, Gao M, Tzen KY, Tsai CL, Hsu FM, Cheng AL, et al. Targeting Phosphatidylinositide3-Kinase/Akt pathway by BKM120 for radiosensitization in hepatocellular carcinoma. Oncotarget. 2014;5:3662-72.

205. Chen YH, Wei MF, Wang CW, Lee HW, Pan SL, Gao M, et al. Dual phosphoinositide 3-kinase/mammalian target of rapamycin inhibitor is an effective radiosensitizer for colorectal cancer. Cancer Lett. 2015;357:582-90.

206. Fofaria NM, Qhattal HS, Liu X, Srivastava SK. Nanoemulsion formulations for anti-cancer agent piplartine-characterization, toxicological, pharmacokinetics and efficacy studies. Int J Pharm. 2016;498:12-22.

207. Venkatesan J, Alam MS, Hong EJ, Kim SK, Shim MS. Preparation of piperlongumine-loaded chitosan nanoparticles for safe and efficient cancer therapy. RSC Advances. 2016;6:79307-16. 
208. Patel K, Chowdhury N, Doddapaneni R, Boakye CHA, Godugu C, Singh M. Piperlongumine for enhancing oral bioavailability and cytotoxicity of docetaxel in triple-negative breast cancer. J Pharm Sci. 2015;104:4417-26.

209. Bezerra DP, Pessoa C, Moraes MO, Costa-Lotufo LV, Rubio Gouvea D, Jabor VAP, et al. Sensitive method for determination of piplartine, an alkaloid amide from piper species, in rat plasma samples by liquid chromatography-tandem mass spectrometry. Química Nova. 2012;35:460-5.

210. Liu Y, Chang Y, Yang C, Sang Z, Yang T, Ang W, et al. Biodegradable nanoassemblies of piperlongumine display enhanced anti-angiogenesis and anti-tumor activities. Nanoscale. 2014;6:4325-37.

211. Choi DG, Venkatesan J, Shim MS. Selective anticancer therapy using pro-oxidant drug-loaded chitosanfucoidan nanoparticles. Int J Mol Sci. 2019;20:3220.

212. Liu Q, Zhao D, Zhu X, Chen H, Yang Y, Xu J, et al. Coloaded nanoparticles of paclitaxel and piperlongumine for enhancing synergistic antitumor activities and reducing toxicity. J Pharm Sci. 2017;106:3066-75.

213. Lee HN, Jin HO, Park JA, Kim JH, Kim JY, Kim B, et al. Heme oxygenase-1 determines the differential response of breast cancer and normal cells to piperlongumine. Mol Cells. 2015;38:327-35. 